\title{
The sensitivity of Southern Ocean aerosols and cloud microphysics to sea spray and sulfate aerosol production in the HadGEM3-GA7.1 chemistry-climate model
}

\author{
Laura E. Revell ${ }^{1}$, Stefanie Kremser ${ }^{2}$, Sean Hartery ${ }^{1}$, Mike Harvey ${ }^{3}$, Jane P. Mulcahy ${ }^{4}$, Jonny Williams ${ }^{3}$, \\ Olaf Morgenstern ${ }^{3}$, Adrian J. McDonald ${ }^{1}$, Vidya Varma ${ }^{3}$, Leroy Bird ${ }^{2}$, and Alex Schuddeboom ${ }^{1}$ \\ ${ }^{1}$ School of Physical and Chemical Sciences, University of Canterbury, Christchurch, New Zealand \\ ${ }^{2}$ Bodeker Scientific, Alexandra, New Zealand \\ ${ }^{3}$ National Institute of Water and Atmospheric Research, Wellington, New Zealand \\ ${ }^{4}$ Met Office, Exeter, UK
}

Correspondence: Laura E. Revell (laura.revell@ canterbury.ac.nz)

Received: 3 July 2019 - Discussion started: 15 August 2019

Revised: 4 November 2019 - Accepted: 6 November 2019 - Published: 17 December 2019

\begin{abstract}
With low concentrations of tropospheric aerosol, the Southern Ocean offers a "natural laboratory" for studies of aerosol-cloud interactions. Aerosols over the Southern Ocean are produced from biogenic activity in the ocean, which generates sulfate aerosol via dimethylsulfide (DMS) oxidation, and from strong winds and waves that lead to bubble bursting and sea spray emission. Here, we evaluate the representation of Southern Ocean aerosols in the Hadley Centre Global Environmental Model version 3, Global Atmosphere 7.1 (HadGEM3-GA7.1) chemistry-climate model. Compared with aerosol optical depth (AOD) observations from two satellite instruments (the Moderate Resolution Imaging Spectroradiometer, MODIS-Aqua c6.1, and the Multi-angle Imaging Spectroradiometer, MISR), the model simulates too-high AOD during winter and too-low AOD during summer. By switching off DMS emission in the model, we show that sea spray aerosol is the dominant contributor to AOD during winter. In turn, the simulated sea spray aerosol flux depends on near-surface wind speed. By examining MODIS AOD as a function of wind speed from the ERA-Interim reanalysis and comparing it with the model, we show that the sea spray aerosol source function in HadGEM3-GA7.1 overestimates the wind speed dependency. We test a recently developed sea spray aerosol source function derived from measurements made on a Southern Ocean research voyage in 2018. In this source function, the wind speed dependency of the sea spray aerosol flux is less
\end{abstract}

than in the formulation currently implemented in HadGEM3GA7.1. The new source function leads to good agreement between simulated and observed wintertime AODs over the Southern Ocean; however, it reveals partially compensating errors in DMS-derived AOD. While previous work has tested assumptions regarding the seawater climatology or sea-air flux of DMS, we test the sensitivity of simulated AOD, cloud condensation nuclei and cloud droplet number concentration to three atmospheric sulfate chemistry schemes. The first scheme adds DMS oxidation by halogens and the other two test a recently developed sulfate chemistry scheme for the marine troposphere; one tests gas-phase chemistry only, while the second adds extra aqueous-phase sulfate reactions. We show how simulated sulfur dioxide and sulfuric acid profiles over the Southern Ocean change as a result and how the number concentration and particle size of the soluble Aitken, accumulation and coarse aerosol modes are affected. The new DMS chemistry scheme leads to a $20 \%$ increase in the number concentration of cloud condensation nuclei and cloud droplets, which improves agreement with observations. Our results highlight the importance of atmospheric chemistry for simulating aerosols and clouds accurately over the Southern Ocean. 


\section{Introduction}

Clouds and aerosols play an important role in Earth's energy balance by absorbing and scattering solar and terrestrial radiation. However, aerosol-radiation and aerosol-cloud interactions are leading sources of uncertainty in determining human influences on climate (Myhre and Shindell, 2013). The Southern Ocean, one of the cloudiest regions on Earth, is remote from anthropogenic sources of aerosol, thus making it an ideal environment in which to study aerosol-cloud interactions (Hamilton et al., 2014). Clouds forming in pristine regions such as over the Southern Ocean are highly sensitive to aerosol perturbations (Koren et al., 2014); however, the specific roles that marine aerosols play in cloud formation are highly uncertain (Brooks and Thornton, 2018).

Marine aerosols are either primary or secondary in origin. Primary aerosols such as sea spray are directly injected into the atmosphere when breaking waves entrain air bubbles, which subsequently form whitecaps and burst. Secondary aerosols such as sulfate aerosol are formed from nucleation of sulfur-containing gases or condensation on pre-existing particles. Sea spray aerosol (SSA) is generated in significant quantities over the Southern Ocean by strong winds and waves (Murphy et al., 1998). SSA is an important contributor to the global-mean clear-sky AOD (Shindell et al., 2013), and its production is highly dependent on wind speed (Smirnov et al., 2003; Mulcahy et al., 2008; Glantz et al., 2009). A significant component of primary marine aerosol is sea salt with some fraction of organics (Fossum et al., 2018). Marine organic aerosols, along with sulfate aerosols, result from biogenic activity in the ocean (O'Dowd et al., 2004). Marine phytoplankton produce dimethylsulfoniopropionate (DMSP), which is broken down into several products including dimethylsulfide (DMS). Oceanic DMS emissions are the main source of atmospheric sulfur over the Southern Ocean, with an estimated $28.1 \mathrm{TgS}$ transferred from the oceans globally into the atmosphere each year (Lana et al., 2011). Around coastal Antarctica, melting of sea ice elevates the seawater DMS concentration (Trevena and Jones, 2006), leading to a seasonal anti-correlation between sea ice extent and aerosol concentration (Gabric et al., 2018). When DMS is emitted into the atmosphere, it has a lifetime of $1-2 \mathrm{~d}$ and undergoes a series of chemical reactions to form sulfur dioxide $\left(\mathrm{SO}_{2}\right)$ and is further oxidised to form sulfuric acid and sulfate aerosol. Alternative oxidation pathways result in some DMS sulfur forming methane sulfonic acid (MSA).

Aerosol particles emitted into the atmosphere can grow in size via condensation and coagulation. Depending on the aerosol composition and meteorological conditions such as the cloud base updraft velocity (Rosenfeld et al., 2014), particles larger than $\gtrsim 50 \mathrm{~nm}$ in diameter can be "activated" to cloud condensation nuclei (CCN) around which water vapour can condense and cloud droplets form. Generally speaking, liquid water clouds which have been perturbed by aerosols consist of more but smaller cloud droplets and therefore scat- ter radiation more efficiently (Twomey, 1977; Boucher and Randall, 2013).

Previous work has confirmed that cloud droplet number concentrations $\left(N_{\mathrm{d}}\right)$ over the Southern Ocean are correlated with marine biogenic activity (Thomas et al., 2010; Woodhouse et al., 2010). Meskhidze and Nenes (2006) identified that observed $N_{\mathrm{d}}$ over a large phytoplankton bloom was twice as large compared to a region distant from the bloom. More recently, McCoy et al. (2015) found that $N_{\mathrm{d}}$ is spatially correlated with regions of high chlorophyll $a$ and that the spatiotemporal variability in $N_{\mathrm{d}}$ is found to be driven mostly by high concentrations of sulfate aerosol at lower southern latitudes and by organic matter in sea spray aerosol at higher latitudes.

The models participating in the fifth phase of the Coupled Model Intercomparison Project (CMIP5) simulated Southern Ocean sea surface temperature (SST) biases which are primarily linked to cloud-related errors in shortwave radiation (Hyder et al., 2018). SST biases affect the position of the storm track (Ceppi et al., 2014), which leads to cascading errors in global climate models across the Southern Hemisphere and reduces confidence in projections of climate change and climate extremes in this region (Trenberth and Fasullo, 2010).

To understand potential connections between the representation of aerosols and clouds via the aerosol indirect effect, we investigate the representation of marine aerosols over the Southern Ocean in the Hadley Centre Global Environmental Model version 3, Global Atmosphere 7.1 (HadGEM3GA7.1). An evaluation of cloud representation in the predecessor HadGEM3-GA7.0 model suggests that significant errors exist in the cloud scheme over the Southern Ocean, but they partially compensate for one another (Schuddeboom et al., 2019). Furthermore, the aerosol forcing and climate feedback in this model are highly sensitive to the representation of DMS-derived sulfate aerosol (Bodas-Salcedo et al., 2019).

HadGEM3-GA7.1 is described in Sect. 2.1, and simulated AOD is evaluated relative to observations in Sect. 3.1. We then show how biases in simulated AOD during winter months can be addressed by implementing a new SSA source function derived from measurements collected on the Southern Ocean (Sect. 3.2). Finally, while much prior work has focused on testing the sensitivity of Southern Ocean clouds and aerosols to the choice of DMS seawater climatology and/or the DMS sea-air transfer function (Mahajan et al., 2015; Boucher et al., 2003; Fiddes et al., 2018; Korhonen et al., 2008; Woodhouse et al., 2010), we have investigated atmospheric DMS chemistry. We performed sensitivity tests in which different gas-phase and aqueous-phase sulfate chemistry schemes have been implemented. The resulting changes in simulated aerosols and cloud microphysics are shown in Sect. 3.3. 


\section{Methods}

\subsection{Model description}

Simulations were performed with HadGEM3-GA7.1 (Walters et al., 2019; Mulcahy et al., 2018), which exhibits more realistic aerosol effective radiative forcing compared with preceding versions (Mulcahy et al., 2018). Aerosol emission, evolution and deposition are simulated with the Global Model of Aerosol Processes (GLOMAP-mode), in which sulfate, sea salt, black carbon and particulate organic matter aerosol are represented in five log-normal size modes. These correspond to particle size ranges of $\leq 10 \mathrm{~nm}$ (nucleation mode), 10-100 nm (Aitken mode), 100-1000 nm (accumulation mode) and $\geq 1000 \mathrm{~nm}$ (coarse mode) (Mann et al., 2010). All modes are soluble, and an insoluble Aitken mode is also included. Mineral dust is represented in the model using a bin emission scheme (Woodward, 2001).

Aerosol-cloud interactions are represented via the UKCAActivate scheme (West et al., 2014), which simulates the number of aerosols activated into cloud droplets. CCN are defined as aerosols with a diameter $\geq 50 \mathrm{~nm}$, which is the minimum size of aerosol that activates with a supersaturation of approximately $0.3 \%$ (Lee et al., 2013). The number of activated aerosols is calculated via Köhler theory and depends on aerosol size, composition and number, along with the local temperature, pressure and vertical velocity (AbdulRazzak and Ghan, 2000). Because the grid cell sizes in global models are too large to resolve cloud base updraft velocity, a probability density function represents the likely distribution of vertical velocity within each grid box at each time step. The cloud droplet number concentration $\left(N_{\mathrm{d}}\right)$ is calculated from the number of activated aerosols at the cloud base, weighted by this probability density function (Mulcahy et al., 2018). The number of cloud droplets subsequently influences the cloud albedo, as clouds with larger $N_{\mathrm{d}}$ (and smaller droplets) are optically brighter (Twomey, 1977).

HadGEM3-GA7.1 scales marine DMS emissions by a factor of 1.7 to account for missing sources of marine organics, which yields a better representation of $N_{\mathrm{d}}$ compared with observations (Mulcahy et al., 2018). Here, we use a modified configuration of the model, GA7.1-mod, which includes marine organics instead of DMS emission scaling. Furthermore, the GA7.1 standard configuration uses a simplified chemistry scheme, whereby chemical oxidants such as $\mathrm{O}_{3}, \mathrm{OH}, \mathrm{NO}_{3}$ and $\mathrm{HO}_{2}$ are prescribed as "offline" monthly-mean climatologies in order to reduce computational time. In this study, the model used an online chemistry scheme, StratTrop (also known as CheST - Chemistry of the Stratosphere and Troposphere), which is a combination of the stratospheric and tropospheric chemistry schemes described by Morgenstern et al. (2009) and O'Connor et al. (2014), respectively.

The StratTrop scheme uses a Newton-Raphson solver and accounts for DMS oxidation via the gas-phase and aqueousphase reactions shown in Table 1. The oxidation of DMS by
$\mathrm{OH}$ proceeds by both an addition and abstraction pathway (the first two reactions listed in Table 1), and can produce $\mathrm{SO}_{2}$ and MSA. The relative yields of these products are important, as $\mathrm{SO}_{2}$ leads to new particle formation, while other products such as MSA condense on existing particles, therefore increasing their size (von Glasow and Crutzen, 2004; Hoffmann et al., 2016).

Gas-phase $\mathrm{SO}_{2}$ enters the liquid phase via an equilibrium approach (Warneck, 2000) described by Henry's law. Because $\mathrm{SO}_{2}$ dissociates in the aqueous-phase (Reactions $\mathrm{R} 1$ and R2), it is more soluble than the equilibrium Henry's law constant $\left(K_{H}\right)$ implies.

$\mathrm{SO}_{2} \rightleftharpoons \mathrm{H}^{+}+\mathrm{HSO}_{3}^{-}$
$\mathrm{HSO}_{3}^{-} \rightleftharpoons \mathrm{H}^{+}+\mathrm{SO}_{3}^{2-}$

Therefore, the model uses an effective constant $\left(K_{H_{\text {eff }}}\right)$ which for $\mathrm{SO}_{2}$ is related to $K_{H}$ by Eq. (1).

$K_{H_{\text {eff }}}=K_{H}\left(1+\frac{k_{\mathrm{R} 1}}{\left[\mathrm{H}^{+}\right]}+\frac{k_{\mathrm{R} 1} k_{\mathrm{R} 2}}{\left[\mathrm{H}^{+}\right]^{2}}\right)$

$k_{\mathrm{R} 1}$ and $k_{\mathrm{R} 2}$ are the equilibrium constants for the aqueousphase dissociations shown in Reactions (R1) and (R2). The hydrogen ion concentration $\left(\mathrm{H}^{+}\right)$is set as a global number in the model, equivalent to a constant $\mathrm{pH}$ of 5 .

SSA is generated via a wind-speed-dependent parameterisation based on whitecap coverage (Gong, 2003). This function is based on the semi-empirical function by Monahan et al. (1986) but improves the representation of small particles less than $0.1 \mu \mathrm{m}$ in diameter. According to Gong (2003), the number of seawater droplets generated per square metre of sea surface, per increment of particle radius over 20 size bins, is calculated via Eq. (2):

$\frac{\mathrm{d} F}{\mathrm{~d} r}=1.373 u_{10}^{3.41} r^{-A}\left(1+0.057 r^{3.45}\right) \times 10^{1.607 e^{-B^{2}}}$.

The exponential terms $A$ and $B$ are defined by Eqs. (3) and (4):

$$
\begin{aligned}
& A=4.7(1+\Theta r)^{-0.017 r^{-1.44},} \\
& B=\frac{(0.433-\log (r))}{0.433},
\end{aligned}
$$

where $r$ is the particle radius at a relative humidity of $80 \%$, $\Theta$ is an adjustable parameter that controls the shape of the size distributions, and $u_{10}$ is the scalar horizontal wind speed at $10 \mathrm{~m}$ above the surface.

\subsection{Simulations performed}

A 20-year reference simulation ("REF") was performed from 1989 to 2008 to evaluate the model. SSTs and greenhouse gas concentrations were based on observations. Emissions of $\mathrm{NO}_{x}, \mathrm{CH}_{4}, \mathrm{CO}, \mathrm{SO}_{2}$, isoprene, monoterpenes, ethane, 
Table 1. Current StratTrop sulfate chemistry scheme.

\begin{tabular}{llrl}
\hline Gas-phase reactions & $k_{298}\left[\mathrm{~cm}^{3} \mathrm{~s}^{-1}\right]^{\mathrm{a}}$ & $-E_{\mathrm{a}} / R[\mathrm{~K}]^{\mathrm{b}}$ & Reference \\
\hline $\mathrm{DMS}+\mathrm{OH} \rightarrow \mathrm{SO}_{2}$ & $1.20 \times 10^{-11}$ & -260 & Pham et al. (1995) \\
$\mathrm{DMS}+\mathrm{OH} \rightarrow \mathrm{SO}_{2}+\mathrm{MSA}$ & $3.04 \times 10^{-12}$ & 350 & Pham et al. (1995) \\
$\mathrm{DMS}+\mathrm{NO}_{3} \rightarrow \mathrm{SO}_{2}$ & $1.90 \times 10^{-13}$ & 500 & Pham et al. (1995) \\
$\mathrm{DMS}+\mathrm{O}\left({ }^{3} \mathrm{P}\right) \rightarrow \mathrm{SO}_{2}$ & $1.30 \times 10^{-11}$ & 410 & Sander et al. (2006), Weisenstein et al. (1997) \\
$\mathrm{SO}_{2}+\mathrm{OH} \rightarrow \mathrm{SO}_{3}+\mathrm{HO}_{2}$ & See note & & Pham et al. (1995) \\
\hline Aqueous-phase reactions & $k_{298}\left[\mathrm{M}^{-1} \mathrm{~s}^{-1}\right]$ & $-E_{\mathrm{a}} / R[\mathrm{~K}]$ & Reference \\
\hline $\mathrm{HSO}_{3}^{-}+\mathrm{H}_{2} \mathrm{O}_{2(\mathrm{aq})}+\mathrm{H}^{+} \rightarrow \mathrm{SO}_{4}^{2-}+2 \mathrm{H}^{+}+\mathrm{H}_{2} \mathrm{O}_{(\mathrm{aq})}$ & $7.45 \times 10^{7}$ & -4430 & Kreidenweis et al. (2003) \\
$\mathrm{HSO}_{3}^{-}+\mathrm{O}_{3(\mathrm{aq})} \rightarrow \mathrm{SO}_{4}^{2-}+\mathrm{H}^{+}+\mathrm{O}_{2(\mathrm{aq})}$ & $3.50 \times 10^{5}$ & -5530 & Kreidenweis et al. (2003) \\
$\mathrm{SO}_{3}^{2-}+\mathrm{O}_{3(\mathrm{aq})} \rightarrow \mathrm{SO}_{4}^{2-}+\mathrm{O}_{2(\mathrm{aq})}$ & $1.50 \times 10^{9}$ & -5280 & Kreidenweis et al. (2003) \\
\hline
\end{tabular}

${ }^{\text {a }}$ Rate constant at $298 \mathrm{~K} .{ }^{\mathrm{b}}$ Activation temperature. ${ }^{\mathrm{c}}$ Low-pressure limit: $3.3 \times 10^{-31}(300 / T)^{3.3} \mathrm{~cm}^{6}$ molecule ${ }^{-2} \mathrm{~s}^{-1}$; high-pressure limit: $1.5 \times 10^{-12} \mathrm{~cm}^{3}$ molecule $\mathrm{s}^{-1}$.

propane, formaldehyde, acetaldehyde, acetone, $\mathrm{NH}_{3}$, black carbon and organic carbon were prescribed based on the year 2000 (Lamarque et al., 2010). A further eight sensitivity simulations were performed, each of 10-year duration, from 1989 to 1998 . These were designed to test the sensitivity of simulated aerosols to the choice of SSA source function and sulfate chemistry scheme, and are summarised in Table 2. All simulations used the DMS seawater climatology of Lana et al. (2011) and the DMS sea-air exchange parameterisation of Liss and Merlivat (1986). Simulations were run with N96 horizontal resolution (i.e. grid sizes $1.875^{\circ} \times 1.25^{\circ}$ in size) and 85 levels between the surface and $85 \mathrm{~km}$.

Analysis of aerosol measurements made on a 2018 Tangaroa research voyage on the Southern Ocean indicate that the dependency of SSA production on near-surface wind speed $\left(u_{10}^{3.41}\right)$ is overestimated by a factor of $2-4$ via the Gong (2003) source function (Eq. 2). Recent research by Hartery et al. (2019) indicates that Eq. (5) with SSA production dependent on $u_{10}^{2.8}$ is a better fit to observed SSA concentrations in an environment dominated by high wind speeds such as the Southern Ocean. The "SSF" (SSA source function) simulation therefore aims to test this using HadGEM3-GA7.1mod. CHEM1-SSF, CHEM2-SSF and CHEM3-SSF also use the SSA source function described by Eq. (5), in combination with different sulfate chemistry schemes as described below.

$\frac{\mathrm{d} F}{\mathrm{~d} r}=2.6 u_{10}^{2.8} r^{-A}\left(1+0.057 r^{3.45}\right) \times 10^{1.607 e^{-B^{2}}}$

The Hartery et al. (2019) SSA source function is based on a series of in situ measurements of the total suspended sea spray concentration within the Southern Ocean boundary layer. The total concentration of sea spray was constrained from the number concentration size spectra measured with a PCASP-100X optical particle counter during a voyage from Wellington, New Zealand, to the Ross Sea in FebruaryMarch 2018.

After the voyage, the Lagrangian particle trajectory model FLEXPART-WRF was used to develop source-receptor relations between the upwind environment and the in situ mea- surements. The source-receptor framework acted as a bridge through which several different formulas for the sea spray source function could be optimised. The newly optimised functions all found that the Gong (2003) parameterisation produced too much sea spray at high wind speeds, as described by Hartery et al. (2019) and previous studies including Madry et al. (2011), Jaeglé et al. (2011) and Spada et al. (2015).

One of the newly optimised parameterisations developed by Hartery et al. (2019) took a power-law form (i.e. Eq. 5), similar to the Gong (2003) parameterisation (Eq. 2). We tested this parameterisation, as it was straightforward to implement in HadGEM3-GA7.1. Hartery et al. (2019) show that the two power-law parameterisations differ primarily at high wind speeds, which are commonly observed over the Southern Ocean. For example, when $u_{10}=4 \mathrm{~m} \mathrm{~s}^{-1}$, both parameterisations predict the same SSA flux. However, when $u_{10}=11 \mathrm{~m} \mathrm{~s}^{-1}$, the Hartery et al. (2019) SSA parameterisation predicts a SSA flux which is $40 \%$ smaller than that predicted by Gong (2003).

Hartery et al. (2019) validated their newly optimised parameterisations by comparing predicted SSA concentrations against airborne data collected on HIAPER (the NSF/NCAR High-performance Instrumented Airborne Platform for Environmental Research) as part of the SOCRATES (Southern Ocean Clouds, Radiation, Aerosol Transport Experimental Study) campaign. The goodness of fit between predictions and airborne measurements validated the use of the new parameterisations (including Eq. 5) over the Southern Ocean.

DMS oxidation chemistry is complex (von Glasow and Crutzen, 2004); however, the set of reactions describing the conversion of gaseous DMS into sulfate aerosol in StratTrop (Table 1) is simplified due to the computational cost of calculating chemical reaction rates. We tested three alternative reaction schemes with incremental increases in complexity, with the aim of identifying how sensitive Southern Ocean aerosols and clouds are to the choice of chemistry scheme. The three sulfate chemistry schemes investi- 
Table 2. HadGEM3-GA7.1-mod simulations performed.

\begin{tabular}{|c|c|c|c|c|}
\hline Experiment & $\begin{array}{l}\text { SSA source } \\
\text { function }\end{array}$ & $\begin{array}{l}\text { DMS emission } \\
\text { scaling }\end{array}$ & Gas-phase DMS chemistry & $\begin{array}{l}\text { Aqueous-phase } \\
\text { sulfate chemistry }\end{array}$ \\
\hline REF & Gong (2003) & 1 & StratTrop & StratTrop \\
\hline SSF & Hartery et al. (2019) & 1 & StratTrop & StratTrop \\
\hline NODMS & Gong (2003) & 0 & StratTrop & StratTrop \\
\hline CHEM1 & Gong (2003) & 1 & StratTrop with DMS $+\mathrm{BrO}$ and DMS $+\mathrm{Cl}$ & StratTrop \\
\hline CHEM2 & Gong (2003) & 1 & Chen et al. (2018) & StratTrop \\
\hline CHEM3 & Gong (2003) & 1 & Chen et al. (2018) & Chen et al. (2018) \\
\hline CHEM1-SSF & Hartery et al. (2019) & 1 & StratTrop with DMS $+\mathrm{BrO}$ and DMS $+\mathrm{Cl}$ & StratTrop \\
\hline CHEM2-SSF & Hartery et al. (2019) & 1 & Chen et al. (2018) & StratTrop \\
\hline CHEM3-SSF & Hartery et al. (2019) & 1 & Chen et al. (2018) & Chen et al. (2018) \\
\hline
\end{tabular}

In the Gong (2003) SSA source function, SSA generation is dependent on $u_{10}^{3.41}$, while in Hartery et al. (2019), it depends on $u_{10}^{2.8}$. See Table 1 for more details on the StratTrop chemistry scheme and Table 3 for more details on the Chen et al. (2018) chemistry scheme.

gated in our CHEM1, CHEM2 and CHEM3 simulations are described in Table 3. The CHEM1 and CHEM2 sensitivity simulations use the same aqueous-phase sulfate chemistry scheme as REF (i.e. the default StratTrop scheme included in HadGEM3-GA7.1-mod) but with increased complexity of the gas-phase chemistry. CHEM1 includes DMS oxidation by halogens as they have been shown to play an important role in the remote marine atmosphere (Boucher et al., 2003; von Glasow and Crutzen, 2004; Chen et al., 2018). CHEM2 includes a gas-phase DMS oxidation scheme based on the scheme recently developed for the marine troposphere by Chen et al. (2018). CHEM3 is identical to CHEM2 except that additional aqueous-phase sulfate reactions are included. This scheme is based on the aqueous-phase scheme by Chen et al. (2018); however, the oxidation reactions by $\mathrm{OH}$ are excluded as $\mathrm{OH}$ uptake into cloud droplets is subject to numerous uncertainties (Chen et al., 2018) and is not currently implemented in HadGEM3-GA7.1-mod. The new scheme also includes aqueous-phase treatment of MSA, which is treated as a sink of DMS in HadGEM3-GA7.1-mod and does not oxidise to form aerosol. In the NODMS simulation, DMS emissions are switched off to help isolate its role in the annual AOD cycle over the Southern Ocean.

\subsection{Observational data sets}

\subsubsection{Satellite-based observations}

Model output is compared to daily-mean aerosol optical depth (AOD) data derived from Moderate Resolution Imaging Spectroradiometer (MODIS)-Aqua measurements, collection 6.1 (Platnick et al., 2003; Sayer et al., 2014) and monthly-mean AOD derived from the Multi-angle Imaging Spectroradiometer (MISR). MODIS is a passive imaging radiometer that measures reflected solar and emitted thermal radiation across a $2330 \mathrm{~km}$ swath, providing near-daily global coverage over land and ocean at the Equator and overlap between orbits at higher latitudes. MODIS was deployed on the Aqua satellite in May 2002. Here, the MODIS level 3 data product with a spatial resolution of $1^{\circ} \times 1^{\circ}$ (latitudelongitude grid) is used for AOD at $550 \mathrm{~nm}$. A number of inconsistencies and potential retrieval problems, which have been identified in past MODIS products, have been remedied in MODIS collection 6.1. The data used in this study were obtained using the combined Deep Blue (land retrieval only) and Dark Target (ocean and land retrieval) approaches (Sayer et al., 2014). In this study, we use MODIS measurements from 2003 to 2007 , a period characterised by a notable absence of volcanic eruptions reaching the lower stratosphere as discussed below. Since MODIS data are limited at high latitudes in the visible band, we spatially and temporally colocate MODIS and model data before calculating climatological monthly means (Schutgens et al., 2016).

A previous study by Remer et al. (2008) showed that, over oceans, MODIS-retrieved AOD agrees well (within the expected uncertainties) with observations obtained from the ground-based Aerosol Robotic Network of Sun photometers (AERONET; Holben et al., 1998) more than $60 \%$ of the time. Toth et al. (2013) subsequently showed that MODIS collection 5 data overestimate AOD as observed from AERONET sites at mid-to-high southern latitudes (Dunedin, $45.8^{\circ} \mathrm{S}$, $170.5^{\circ} \mathrm{E}$, and Crozet Islands, $46.4^{\circ} \mathrm{S}, 51.9^{\circ} \mathrm{E}$ ), and this bias is attributed to cloud contamination of the MODIS AOD product. Since then, MODIS data have been reprocessed, implementing a number of improvements in the retrieval algorithm, including the use of a revised cloud mask to account for cloud contamination.

MISR was deployed on Terra, NASA's first Earth Observing System (EOS) spacecraft, on 18 December 1999. MISR views the sunlit Earth simultaneously at nine widely spaced angles in four visible and near-infrared wavelengths, with a swath of approximately $400 \mathrm{~km}$ (Diner et al., 1998). Due to the overlap of the swathes near the poles and their wide separations at the Equator, coverage time varies from 2 to $9 \mathrm{~d}$, respectively. The MISR AOD product has been validated with respect to AERONET (Kahn et al., 2010; Garay et al., 2017) 
Table 3. Reaction schemes tested with the CHEM1, CHEM2 and CHEM3 sensitivity simulations.

\begin{tabular}{|c|c|c|c|}
\hline Gas-phase reactions & $k_{298}\left[\mathrm{~cm}^{3} \mathrm{~s}^{-1}\right]$ & $-E_{\mathrm{a}} / R[\mathrm{~K}]$ & Reference \\
\hline \multicolumn{4}{|l|}{ CHEM1: } \\
\hline $\mathrm{DMS}+\mathrm{OH} \rightarrow \mathrm{SO}_{2}+\mathrm{CH}_{3} \mathrm{O}_{2}+\mathrm{HCHO}$ & $4.69 \times 10^{-12}$ & -280 & Burkholder et al. (2015) \\
\hline $\mathrm{DMS}+\mathrm{OH} \rightarrow 0.6 \mathrm{SO}_{2}+0.4 \mathrm{DMSO}+\mathrm{CH}_{3} \mathrm{O}_{2}$ & $3.04 \times 10^{-12}$ & 350 & Pham et al. (1995) \\
\hline $\mathrm{DMS}+\mathrm{NO}_{3} \rightarrow \mathrm{SO}_{2}+\mathrm{HNO}_{3}+\mathrm{CH}_{3} \mathrm{O}_{2}+\mathrm{HCHO}$ & $1.13 \times 10^{-12}$ & 530 & Burkholder et al. (2015) \\
\hline $\mathrm{DMS}+\mathrm{BrO} \rightarrow \mathrm{DMSO}+\mathrm{Br}$ & $3.39 \times 10^{-13}$ & 950 & Burkholder et al. (2015) \\
\hline $\mathrm{DMS}+\mathrm{O}_{3} \rightarrow \mathrm{SO}_{2}$ & $1.00 \times 10^{-19}$ & 0 & Burkholder et al. (2015), Du et al. (2007) \\
\hline $\mathrm{DMS}+\mathrm{Cl} \rightarrow 0.5 \mathrm{SO}_{2}+0.5 \mathrm{DMSO}+0.5 \mathrm{HCl}+0.5 \mathrm{ClO}$ & $3.40 \times 10^{-10}$ & 0 & Burkholder et al. (2015), Barnes et al. (2006) \\
\hline \multicolumn{4}{|l|}{ CHEM2: as for CHEM1 plus the following reactions: } \\
\hline $\mathrm{DMSO}+\mathrm{OH} \rightarrow 0.95 \mathrm{MSIA}^{\mathrm{a}}+0.05 \mathrm{SO}_{2}$ & $8.94 \times 10^{-11}$ & 800 & Burkholder et al. (2015), von Glasow and Crutzen (2004) \\
\hline $\mathrm{MSIA}+\mathrm{OH} \rightarrow 0.9 \mathrm{SO}_{2}+0.1 \mathrm{MSA}$ & $9.00 \times 10^{-11}$ & 0 & $\begin{array}{l}\text { Burkholder et al. (2015), Hoffmann et al. (2016), } \\
\text { Kukui et al. (2003), Zhu et al. (2006) }\end{array}$ \\
\hline $\mathrm{MSIA}+\mathrm{O}_{3} \rightarrow$ MSA & $2.00 \times 10^{-18}$ & 0 & Lucas and Prinn (2002), von Glasow and Crutzen (2004) \\
\hline $\mathrm{SO}_{2}+\mathrm{OH} \rightarrow \mathrm{H}_{2} \mathrm{SO}_{4}+\mathrm{HO}_{2}$ & See note ${ }^{\mathrm{b}}$ & & Burkholder et al. (2015) \\
\hline Aqueous-phase reactions & $k_{298}\left[\mathrm{M}^{-1} \mathrm{~s}^{-1}\right]$ & $-E_{\mathrm{a}} / R[\mathrm{~K}]$ & Reference \\
\hline \multicolumn{4}{|l|}{ CHEM3: as for CHEM2 plus the following reactions: } \\
\hline $\mathrm{DMS}_{(\mathrm{aq})}+\mathrm{O}_{3(\mathrm{aq})} \rightarrow \mathrm{DMSO}_{(\mathrm{aq})}+\mathrm{O}_{2(\mathrm{aq})}$ & $8.61 \times 10^{8}$ & -2600 & Gershenzon et al. (2001) \\
\hline $\operatorname{MSIA}_{(\mathrm{aq})}+\mathrm{O}_{3(\mathrm{aq})} \rightarrow \mathrm{MSA}_{(\mathrm{aq})}$ & $3.50 \times 10^{7}$ & 0 & Hoffmann et al. (2016) \\
\hline $\mathrm{MSI}^{-\mathrm{c}}+\mathrm{O}_{3(\mathrm{aq})} \rightarrow \mathrm{MS}^{-\mathrm{d}}$ & $2.00 \times 10^{6}$ & 0 & Flyunt et al. (2001) \\
\hline $\mathrm{HSO}_{3}^{-}+\mathrm{HOBr}_{(\mathrm{aq})} \rightarrow \mathrm{SO}_{4}^{2-}+2 \mathrm{H}^{+}+\mathrm{Br}^{-}$ & $3.20 \times 10^{9}$ & 0 & Chen et al. (2016), Chen et al. (2017) \\
\hline $\mathrm{SO}_{3}^{2-}+\mathrm{HOBr}_{(\mathrm{aq})} \rightarrow \mathrm{SO}_{4}^{2-}+\mathrm{H}^{+}+\mathrm{Br}^{-}$ & $5.00 \times 10^{9}$ & 0 & Troy and Margerum (1991) \\
\hline $\mathrm{HSO}_{3}^{-}+\mathrm{H}_{2} \mathrm{O}_{2(\mathrm{aq})}+\mathrm{H}^{+} \rightarrow \mathrm{SO}_{4}^{2-}+2 \mathrm{H}^{+}+\mathrm{H}_{2} \mathrm{O}_{(\mathrm{aq})}$ & $7.45 \times 10^{7}$ & -4760 & Jacob (1986), Kreidenweis et al. (2003) \\
\hline $\mathrm{HSO}_{3}^{-}+\mathrm{O}_{3(\mathrm{aq})} \rightarrow \mathrm{SO}_{4}^{2-}+\mathrm{H}^{+}+\mathrm{O}_{2(\mathrm{aq})}$ & $3.20 \times 10^{5}$ & -4830 & Jacob (1986) \\
\hline $\mathrm{SO}_{3}^{2-}+\mathrm{O}_{3(\mathrm{aq})} \rightarrow \mathrm{SO}_{4}^{2-}+\mathrm{O}_{2(\mathrm{aq})}$ & $1.00 \times 10^{9}$ & -4030 & Jacob (1986) \\
\hline
\end{tabular}

${ }^{a}$ Methanesulfinic acid, $\mathrm{CH}_{3}$ SOOH. ${ }^{\mathrm{b}}$ Low-pressure limit: $3.3 \times 10^{-31}(300 / T)^{4.3} \mathrm{~cm}^{6}$ molecule ${ }^{-2} \mathrm{~s}^{-1}$; high-pressure limit: $1.6 \times 10^{-12} \mathrm{~cm}^{3}$ molecule ${ }^{-1} \mathrm{~s}^{-1}$ as described by Chen et al. $(2018)$. ${ }^{\mathrm{c}} \mathrm{CH}_{3} \mathrm{SOO}^{-1} \cdot{ }^{\mathrm{d}} \mathrm{CH}_{3} \mathrm{SO}_{2} \mathrm{O}^{-1}$.

and also shows good agreement with AOD level 3 data from MODIS (Mehta et al., 2016).

Here, the MISR level 3 data product with a spatial resolution of $0.5^{\circ} \times 0.5^{\circ}$ is used for total AOD at $555 \mathrm{~nm}$, with the AOD retrieval algorithm dependent on surface types such as vegetated areas, dark water bodies and high-contrast terrain (Martonchik et al., 2009). To match the MODIS observation period, MISR measurements from 2003 to 2007 are used in this study. The measurements are temporally colocated with the model data before calculating climatological monthly means.

AOD quantifies the amount of aerosol in the vertical column between the Earth's surface and the top of the atmosphere. Due to the lack of large volcanic eruptions during the period of study, the stratospheric component of AOD over the Southern Ocean is around 0.007 (an absolute value), as indicated by the global stratospheric aerosol data set compiled by Thomason et al. (2018). Therefore, tropospheric aerosols are the dominant contributor to total AOD over the Southern Ocean between 2003 and 2007. Satellite-derived AOD depends on the atmospheric concentration of particulate matter such as sea spray, mineral dust, organic compounds and sulfate originating from the oxidation of atmospheric DMS. As the Southern Ocean is remote from anthropogenic influence, the predominant tropospheric aerosols contributing to AOD are sulfate and sea spray (Gabric et al., 2005).
To evaluate $N_{\mathrm{d}}$ in HadGEM3-GA7.1-mod, we used the "GW14" data set presented by Grosvenor et al. (2018), which is derived from MODIS retrievals. GW14 was originally developed by Grosvenor and Wood (2014) and later extended to 2015. Grosvenor et al. (2018) compare the GW14 data set with another MODIS-derived $N_{\mathrm{d}}$ data set compiled by Bennartz and Rausch (2017) and show that the two data sets are similar over the Southern Ocean, with the Bennartz and Rausch (2017) data set reporting slightly higher values. Grosvenor et al. (2018) note that this is likely related to a lack of screening for any biases in the solar zenith angle in the Bennartz and Rausch (2017) data set. We compiled GW14 $N_{\mathrm{d}}$ data between 2003 and 2015 into climatological monthly means and examined the area-weighted mean over the Southern Ocean. The same procedure was followed for each of the model simulations.

\subsubsection{In situ and flask measurements of DMS}

Surface observations of DMS, which is an important precursor of sulfate aerosol, are relatively rare in the Southern Ocean and Antarctic region. In this study, we rely on observations from research voyages and the measurement stations at Amsterdam Island in the southern Indian Ocean $\left(38^{\circ} \mathrm{S}, 78^{\circ} \mathrm{E}\right)$ and Cape Grim, Tasmania $\left(41^{\circ} \mathrm{S}, 145^{\circ} \mathrm{E}\right)$. Atmospheric flask measurements were obtained from Am- 
sterdam Island between 1987 and 2008 (Sciare et al., 2001) and Cape Grim between 1989 and 1996 (Ayers and Gillett, 2000). Ship-borne measurements were obtained from the SOAP (Surface Ocean Aerosol Production) campaign, which sampled within $42-47^{\circ} \mathrm{S}, 172-180^{\circ} \mathrm{E}$, during February and March 2012 (Law et al., 2017; Bell et al., 2015; Smith et al., 2018), and SOIREE (the Southern Ocean Iron RElease Experiment), which sampled within $42-63^{\circ} \mathrm{S}, 139-172^{\circ} \mathrm{E}$, in February 1999 (Boyd and Law, 2001; Boyd et al., 2000). During SOIREE, DMS was measured in discrete water samples from vertical profiles and whilst underway in air and surface water (Turner et al., 2004). During SOAP, surface water and surface microlayer DMS were measured (Walker et al., 2016) in addition to atmospheric DMS concentrations and emission fluxes (Bell et al., 2015; Smith et al., 2018).

\section{Results and discussion}

\subsection{Evaluation of simulated AOD}

Figure 1 shows climatological monthly zonal-mean AOD between 40 and $60^{\circ} \mathrm{S}$ as simulated by HadGEM3-GA7.1-mod and observed by MODIS and MISR. The seasonality in AOD over the Southern Ocean is similar between MODIS and MISR, as shown previously by Ocko and Ginoux (2017). The model generally agrees with the maximum, minimum and mean AOD observed by MODIS (Fig. 1a, b). However, the simulated seasonal cycle is out of phase. The model simulates too much aerosol in winter (JJA) and too little in summer (DJF) compared with satellite observations (Fig. 1c, d).

As discussed earlier, sulfate aerosol from biogenic sources and SSA predominantly contribute to AOD over the Southern Ocean. By performing a simulation with DMS emissions switched off (the NODMS simulation) and comparing it with the REF simulation (Fig. 2d), it is apparent that the model simulates primarily SSA during winter (July and August, $50-60^{\circ} \mathrm{S}$ ). This result is consistent with the Aerocom (Aerosol Comparisons between Models and Observations) phase II models, which simulate a seasonal maximum in seasalt AOD during winter at southern high latitudes, while sulfate AOD maximises in summertime.

In DJF, AOD is approximately $60 \%$ lower in the NODMS simulation compared with REF, indicating that sulfate aerosol of marine biogenic origin is primarily produced during summertime when increased solar radiation and warmer waters make the ocean more biologically productive. Indeed, measurements at Baring Head $\left(41^{\circ} \mathrm{S}, 179^{\circ} \mathrm{E}\right)$ indicate that sulfate in fine aerosol modes is mostly secondary sulfate from marine DMS emission, exhibiting an annual maximum in summertime, while coarse sulfate aerosol is mainly from sea salt and is relatively constant throughout the year ( $\mathrm{Li}$ et al., 2018).

Total AOD is calculated in HadGEM3-GA7.1 from adding together the individual contributions of dust AOD and the
Aitken-mode (soluble plus insoluble), accumulation-mode and coarse-mode AODs. Aerosol particles in the soluble modes may activate to cloud condensation nuclei, and the contribution to total AOD from these modes is shown in Fig. 2a-c. Coarse-mode aerosol is the major contributor to total AOD due to its size and maximises in Southern Hemisphere autumn, winter and spring (Fig. 2c), implying that it is mostly SSA as discussed above. Accumulation-mode aerosol (Fig. 2b) shows a clear seasonal cycle which maximises during summer (as shown previously by, e.g. Vallina et al., 2007), indicating that this is mostly aerosol of marine biogenic origin. Aitken- and accumulation-mode aerosol increases during springtime at $40^{\circ} \mathrm{S}$, associated with longrange transport of particulate matter from South America, Australia and South Africa (McCluskey et al., 2019).

\subsection{Simulated sea-salt aerosol}

Given that HadGEM3-GA7.1-mod primarily simulates SSA during winter, we now examine SSA production in more detail. Zonal-mean near-surface wind speeds between 40 and $60^{\circ} \mathrm{S}$ are shown in Fig. 3a. The model agrees reasonably well with the ERA-Interim reanalysis (Dee et al., 2011), at least in the zonal mean. However, the actual position of the storm track tends to be zonally shifted in the model (not shown), which is associated with the model's shortwave radiation bias discussed in Sect. 1. While sparse observations over the Southern Ocean lead to some uncertainty regarding the comparative accuracy of near-surface wind data sets in reanalyses, Bracegirdle et al. (2013) indicate that ERA-Interim is the most reliable of contemporary reanalyses. Furthermore, ERA-Interim near-surface winds agree well with other reanalyses such as the National Centers for Environmental Prediction Climate Forecast System Reanalysis (NCEP/CFSR) and NASA Modern-Era Retrospective analysis for Research and Applications (MERRA) (Bracegirdle et al., 2013).

Wind speeds over the Southern Ocean show a clear seasonality maximising between autumn and spring, and thus we expect more SSA to be produced during this time. As described in Sect. 2.1, the model uses the SSA source function of Gong (2003) in which SSA generation scales according to a power law with wind speed. The correlation between simulated AOD and wind speed is shown for July 2003-2007 in Fig. 4. July was chosen as a representative wintertime month during which wind speeds are high over the Southern Ocean (Fig. 3a) and aerosol predominantly consists of sea salt (Fig. 2d). Comparing this with a similar regression model fit derived from MODIS and ERA-Interim data illustrates that the wind speed dependency of SSA production over the Southern Ocean is overestimated in the model as evidenced by the regression model fits obtained. This is supported by SSA measurements made on the 2018 Tangaroa research voyage, which indicate that SSA production requires a threshold wind speed below which no SSA is produced. The measurements also show that the SSA flux predicted by 

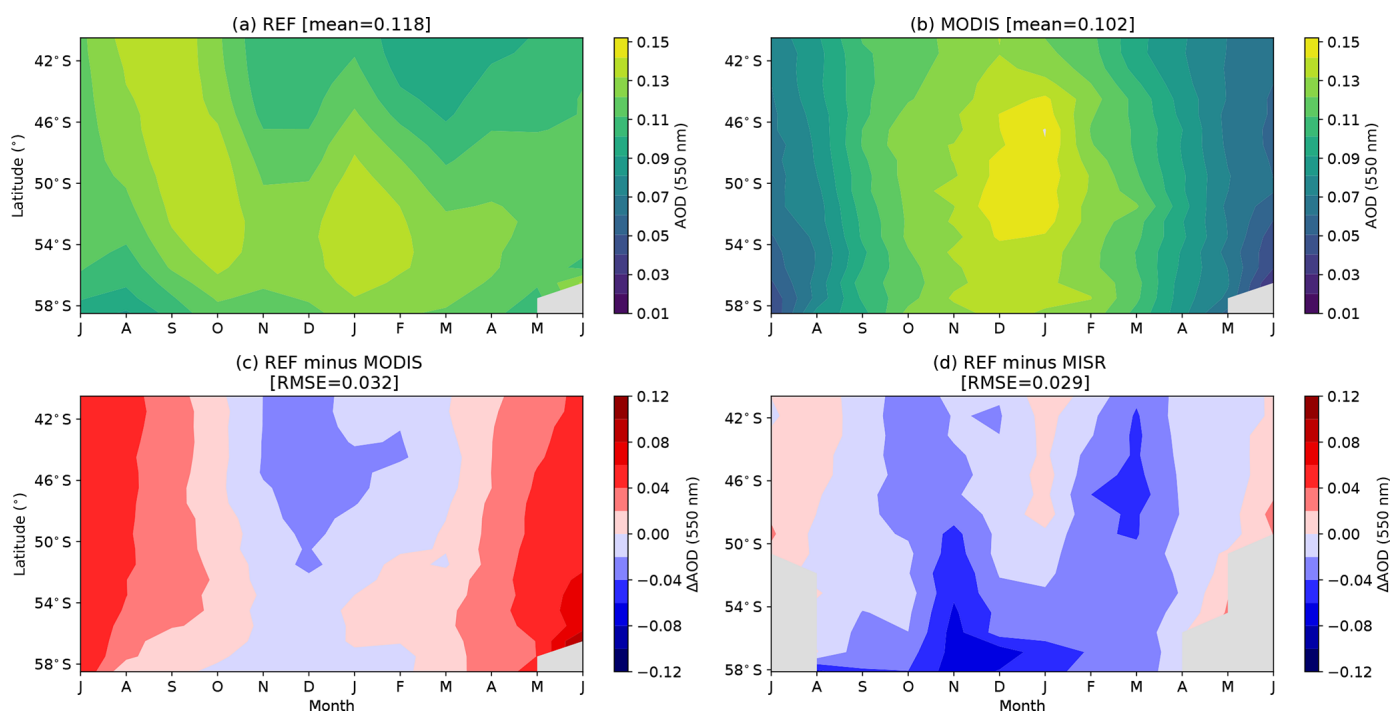

Figure 1. (a) Monthly climatological zonal-mean aerosol optical depth (AOD) at $550 \mathrm{~nm}$ between 2003 and 2007 for the REF simulation performed with the modified HadGEM3-GA7.1 model. Daily-mean model data were temporally co-located with daily-mean MODIS satellite data. The grey shaded area indicates where MODIS data are unavailable, and the mean AOD is indicated in the title. (b) As for panel (a) but showing AOD measured by MODIS-Aqua (the Moderate Resolution Imaging Spectroradiometer) collection 6.1. (c) The difference between HadGEM3-GA7.1-mod and MODIS; i.e. panel (a) minus (b). The root mean square error (RMSE) is indicated in the title. (d) As for panel (c) but showing the difference between HadGEM3-GA7.1-mod and MISR (Multi-angle Imaging Spectroradiometer).
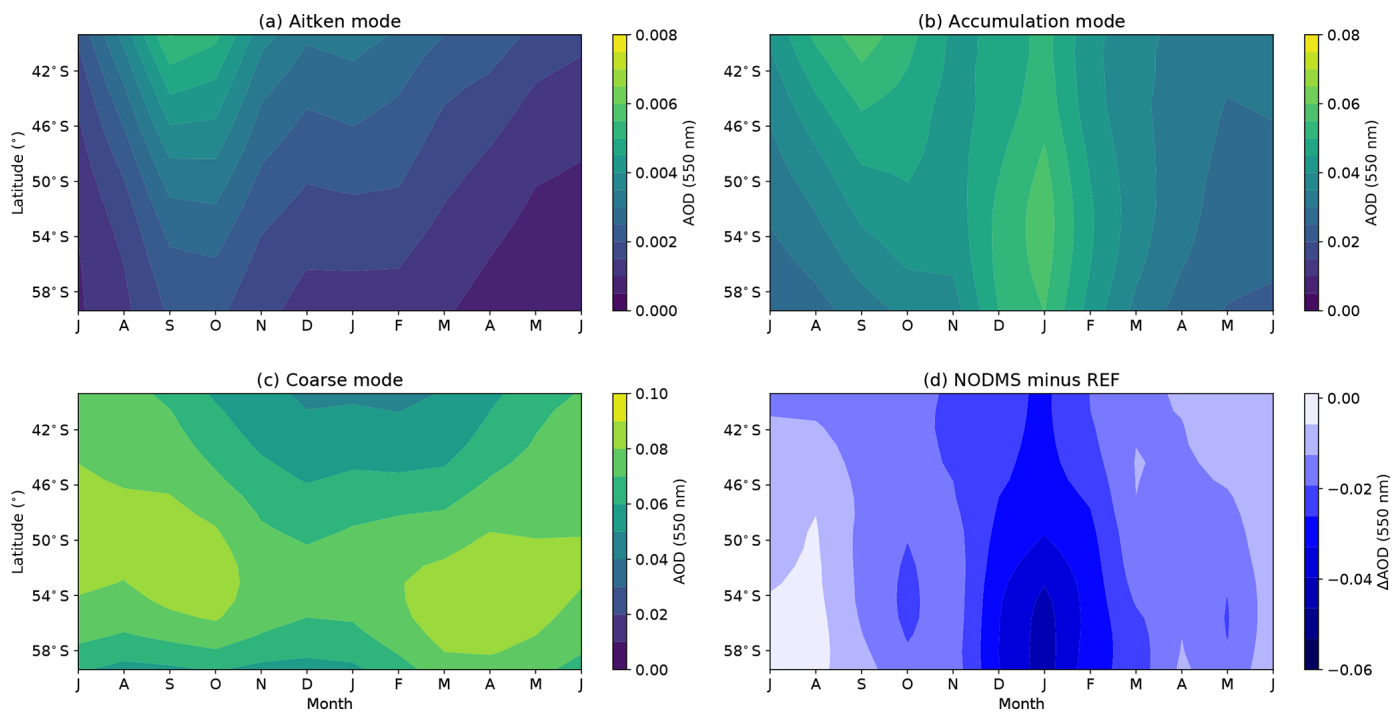

Figure 2. (a) Monthly climatological zonal-mean contribution to AOD at $550 \mathrm{~nm}$ from soluble Aitken-mode AOD in the REF simulation performed with HadGEM3-GA7.1-mod. (b) As for panel (a) but showing accumulation-mode AOD. (c) As for panel (a) but showing coarsemode AOD. (d) Difference in climatological monthly-mean AOD between the REF simulation and NODMS simulation with surface DMS emissions switched off.

the Gong (2003) parameterisation increases too quickly as a function of wind speed. These two effects result in overproduction of SSA at all wind speeds by a factor of 2-4 (Hartery et al., 2019).

AOD over the Southern Ocean in the SSF simulation using the Hartery et al. (2019) source function (see Eq. 5 and Table 2) is shown in Fig. 3b. Compared with the REF simu- lation (Fig. 3c) the reduction in AOD is reasonably uniform throughout the year, with the reduction in coarse-mode AOD (shown for REF in Fig. 2c) between March and November particularly visible. Comparing to MODIS observations, the Hartery et al. (2019) source function performs well during winter months when SSA is the dominant contributor to AOD (Fig. 3d). Changes in aerosol mode number concentra- 

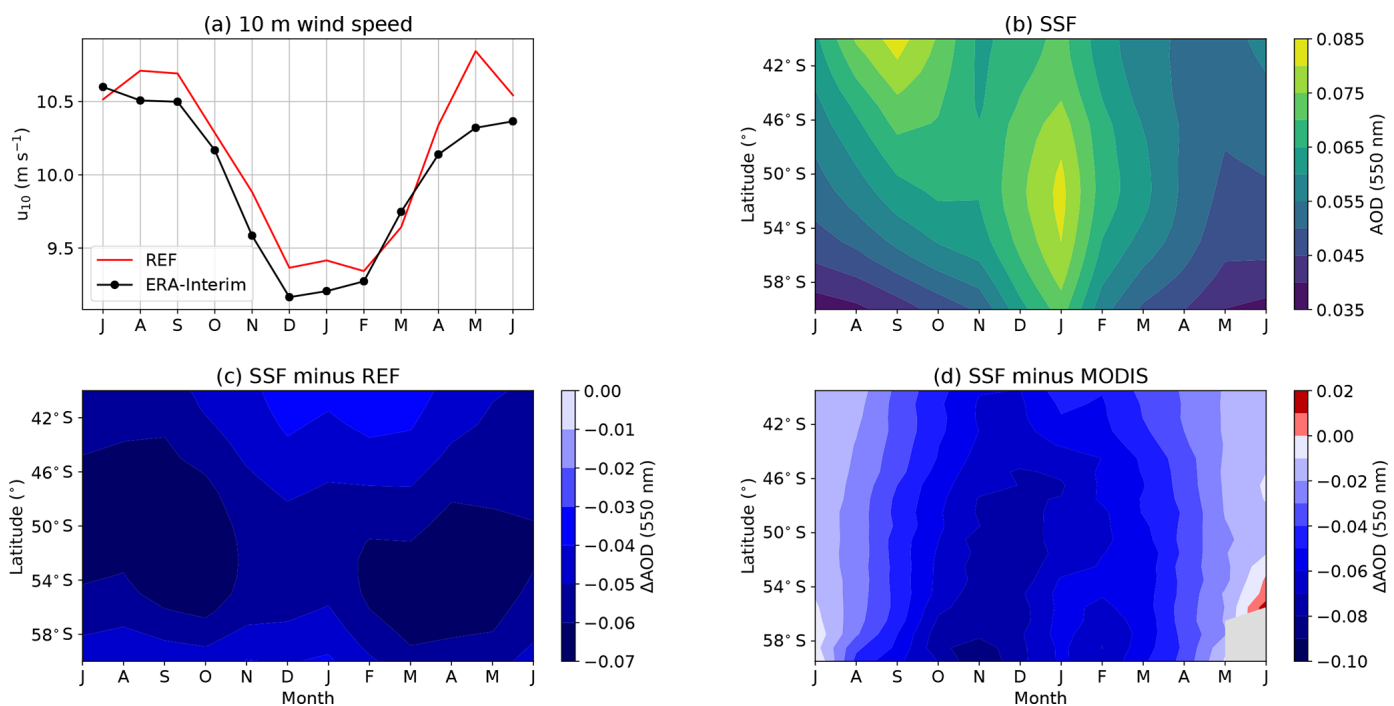

Figure 3. (a) Near-surface $(10 \mathrm{~m})$ climatological monthly-mean wind speed between 40 and $60^{\circ} \mathrm{S}$ in the REF simulation and ERA-Interim reanalysis between 2003 and 2007. (b) Monthly-mean AOD in the SSF sensitivity simulation with the SSA source function changed to that of Hartery et al. (2019). (c) AOD difference between the REF and SSF simulations. (d) AOD difference between MODIS and the SSF simulation.

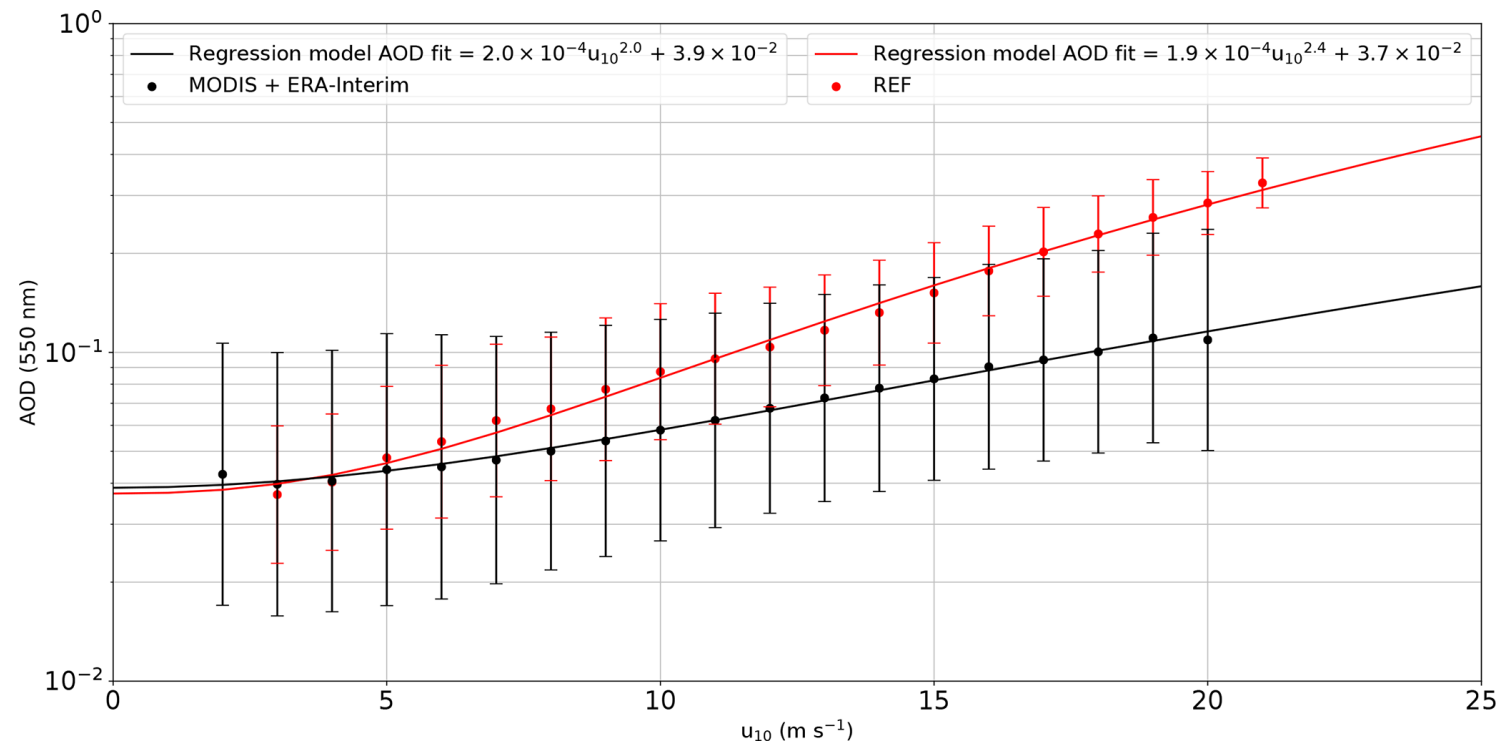

Figure 4. Binned AOD at $550 \mathrm{~nm}$ vs. $10 \mathrm{~m}$ wind speed. Daily averages of AOD were matched to $10 \mathrm{~m}$ wind speeds for all ocean grid cells at latitudes between 40 and $60^{\circ} \mathrm{S}$ for July 2003-2007. These values were then sorted into discretised $1 \mathrm{~m} \mathrm{~s}^{-1}$ bins, and the median AOD in each bin was recorded. Grid cells were considered individually during the binning process (i.e. AOD and wind speeds were not averaged zonally prior to binning). A least-squares regression was performed on the gridded data, and the fit is shown for the REF simulation and ERA-Interim and MODIS data between 2003 and 2007. Days on which there were less than five MODIS observations of AOD in a given $0.5^{\circ} \times 0.5^{\circ}$ grid cell were removed from the analysis.

tions and dry diameters in the SSF simulation are discussed later in Sect. 3.3.

Our finding that the SSA contribution to AOD is overestimated in the REF simulation is consistent with the Atmospheric Chemistry and Climate Model Intercomparison Project (ACCMIP) models, which overestimate annual-mean sea-salt AOD between 50 and $60^{\circ} \mathrm{S}$ compared to observations from AERONET Sun photometers (Shindell et al., 2013). Our results are also consistent with previous work suggesting that the Gong (2003) source function overestimates the SSA dependency on wind speed (Madry et al., 2011). Jaeglé et al. (2011) found that using the GEOS-Chem 
chemical transport model, the Gong (2003) SSA source function led to overestimation of coarse-mode SSA in the atmosphere by a factor of 2-3 at high wind speeds and suggested that the discrepancies are dependent on sea surface temperature. Similarly, Spada et al. (2015) showed that seasalt surface concentrations are overestimated compared with observations at southern high latitudes in chemical transport model simulations using the Gong (2003) source function. However, by implementing a weighting factor based on sea surface temperature as suggested by Jaeglé et al. (2011), their model simulated SSA concentrations that are in closer agreement with observations (Spada et al., 2015).

How SSA should ultimately be represented in global models remains the subject of ongoing research. Along with Jaeglé et al. (2011), other studies have found that SSA concentrations are correlated with sea surface temperature (Mårtensson et al., 2003; Sellegri et al., 2006; Sofiev et al., 2011; Grythe et al., 2014). More recently, Forestieri et al. (2018) demonstrated that variability in seawater composition may have just as large an impact on SSA production as temperature. Nonetheless, our results demonstrate that for the Southern Ocean during winter when SSA is the dominant contributor to AOD, reducing the wind speed dependency of SSA production results in good agreement between the model and observations. However, Fig. 3d points to the existence of partially compensating errors, namely that sulfate aerosol is underestimated in the model during summertime even more than suggested by the REF simulation. Given the importance of sulfur chemistry in the marine atmosphere, we now discuss the CHEM simulations and sensitivity of simulated aerosols and cloud microphysics to the choice of sulfate chemistry scheme.

\subsection{DMS oxidation chemistry}

Seawater DMS from the Lana et al. (2011) climatology used as input to HadGEM3-GA7.1-mod is shown in Fig. 5. Seawater DMS concentrations maximise in austral summer along the Antarctic continent following sea ice melt and the corresponding release of aerosol precursors by phytoplankton which grow on the underside of sea ice (Gabric et al., 2005). In the Lana et al. (2011) climatology, the maximum summertime DMS concentration reached at southern high latitudes during DJF is up to $15 \mathrm{nM}$ lower than in the older Kettle and Andreae (2000) seawater DMS climatology. Using the ECHAM5-HAMMOZ model, Mahajan et al. (2015) showed that use of the Lana et al. (2011) climatology improved the simulation of DMS at Amsterdam Island, particularly during summertime when observed concentrations are large. However, the Lana et al. (2011) climatology includes large uncertainties as it was compiled from cruise observations interpolated to make a global climatology. These uncertainties translate to variations in $N_{\mathrm{d}}$ between 2 and $5 \mathrm{~cm}^{-3}$ in HadGEM3-GA7.1 (Mulcahy et al., 2018).

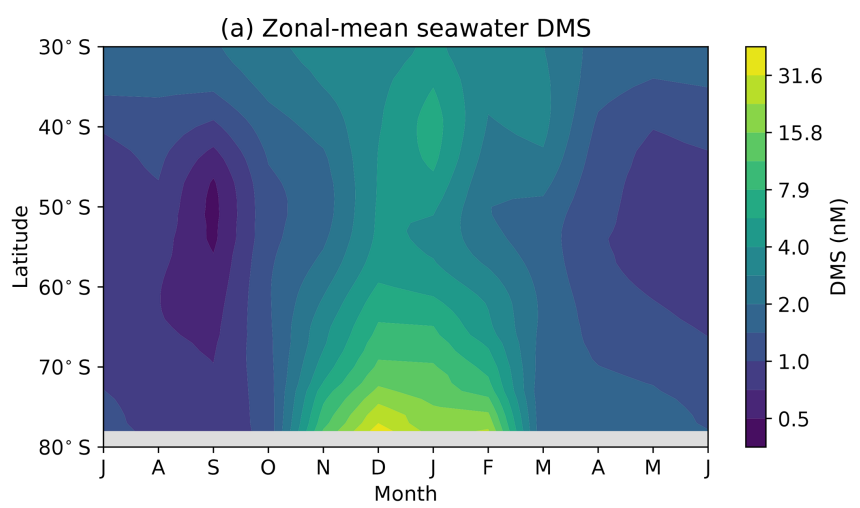

(b) Seawater DMS in January

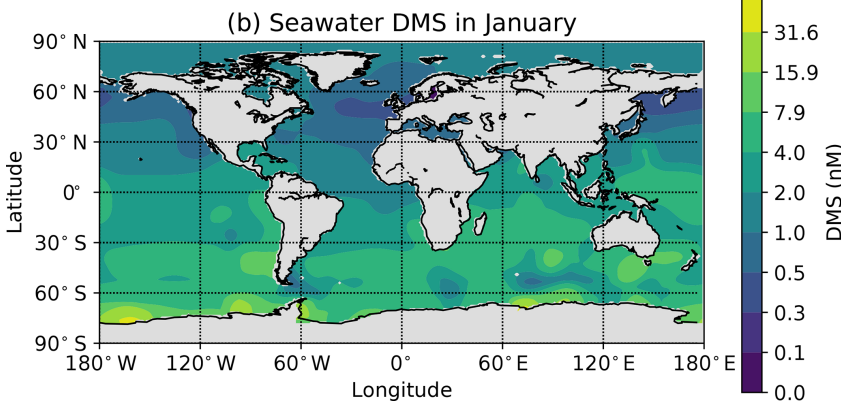

Figure 5. Seawater DMS concentrations from the Lana et al. (2011) climatology used as input to HadGEM3-GA7.1-mod shown for (a) the Southern Ocean as a zonal mean and (b) globally for January.

Simulated surface atmospheric DMS concentrations in the REF simulation agree reasonably well with measurements from the SOAP and SOIREE voyages (Fig. 6a), although the spread in measurements varies by almost 1000 ppt. The model does not capture such a large spread in variability, likely because it provides output averaged over coarse horizontal grid cells, and SOAP sought out the highest chlorophyll-/DMS-containing waters at the time of the voyage. To examine the seasonal cycle in atmospheric DMS, we compare model results with measurements obtained from Amsterdam Island (Fig. 6b) and Cape Grim (Fig. 6c). For both observations and the model, the summertime maximum coincides with the peak of phytoplankton productivity. At Amsterdam Island, the REF simulation underestimates DMS in January by $55 \%$ and overestimates it in July by a factor of 3. However, at Cape Grim, DMS is overestimated throughout the year in the REF simulation and simulates approximately 5 times too much DMS in January. The large DMS concentrations simulated at Cape Grim relate to the Lana et al. (2011) seawater DMS climatology, which shows a region of high DMS productivity nearby (Fig. 5b).

In all three CHEM simulations, the change in the simulated surface atmospheric DMS concentration is negligible relative to the magnitude of the seasonal cycle in DMS (Fig. 6b, c). Figure $7 \mathrm{a}$ shows DMS in the lowest $2 \mathrm{~km}$ of 
(a) Southern Ocean DMS, Feb-Mar

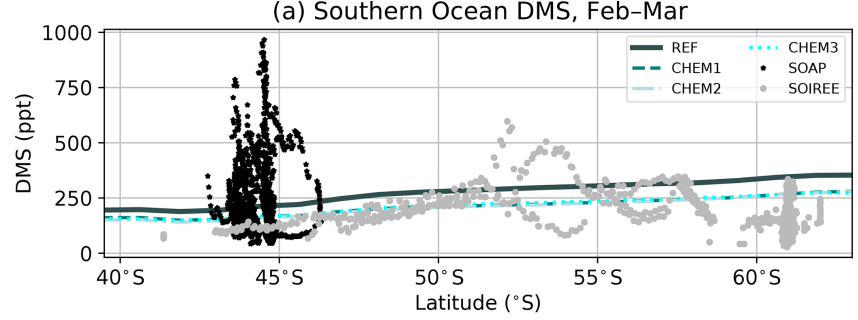

(b) Amsterdam Island DMS $\left(38^{\circ} \mathrm{S}, 78^{\circ} \mathrm{E}\right)$

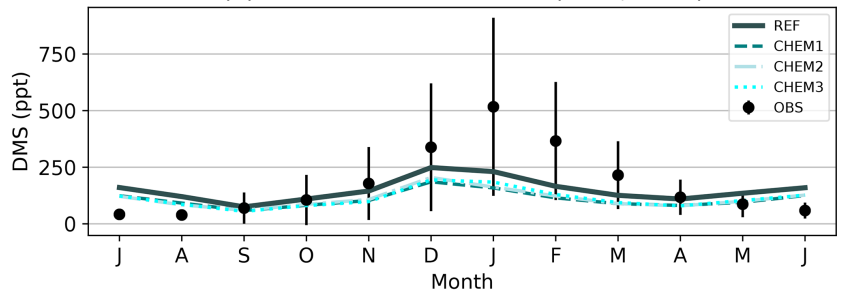

(c) Cape Grim DMS $\left(41^{\circ} \mathrm{S}, 145^{\circ} \mathrm{E}\right)$

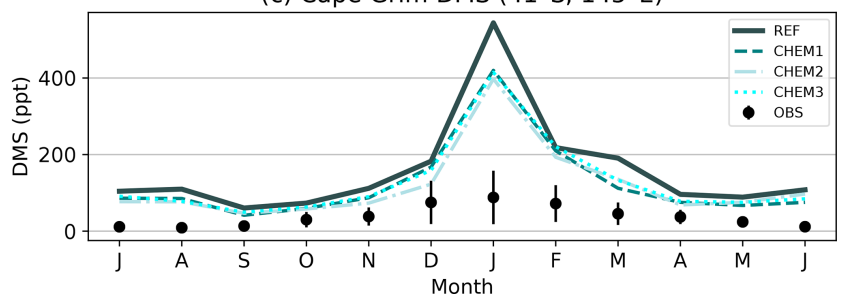

Figure 6. (a) DMS measurements obtained from the Surface Ocean Aerosol Production campaign (SOAP) and the Southern Ocean Iron Release Experiment (SOIREE), compared to simulated surface atmospheric DMS concentrations from the REF, CHEM1, CHEM2 and CHEM3 simulations. Model data are averaged over the combined domain of both voyages $\left(172-180^{\circ} \mathrm{E}\right)$ and show FebruaryMarch climatological means calculated over the period 1989-2008. (b) Climatological monthly-mean surface atmospheric DMS measured at Amsterdam Island between 1987 and 2008 compared to simulated surface atmospheric DMS concentrations at Amsterdam Island in the REF and CHEM simulations. The error bars show the standard deviation on the observed monthly mean. (c) As for panel (b) but showing DMS at Cape Grim between 1989 and 1996.

the atmosphere over the Southern Ocean. In the CHEM simulations, the DMS concentration is $7 \%-13 \%$ larger than in REF. This likely relates to the rate constant for the first $\mathrm{DMS}+\mathrm{OH}$ reaction listed in Tables 1 and 3, which is an order of magnitude smaller in the new scheme tested compared with the existing StratTrop scheme, implying that it will proceed more slowly, and therefore less DMS will be oxidised.

$\mathrm{SO}_{2}$ concentrations decrease with height above $0.5 \mathrm{~km}$ altitude (Fig. 7b), which is the approximate cloud base (Fig. 9). Surface $\mathrm{SO}_{2}$ concentrations are almost 30 ppt lower in the CHEM1 simulation compared with REF. This is likely due to the implementation of reactions between DMS and halogens $(\mathrm{DMS}+\mathrm{BrO}$ and $\mathrm{DMS}+\mathrm{Cl})$, which may convert the sulfur in DMS to DMSO and $\mathrm{SO}_{2}$ (rather than only $\mathrm{SO}_{2}$; see Table 3). In particular, the DMS + BrO reaction has been shown to be particularly important in the remote marine troposphere (Chen et al., 2018; Boucher et al., 2003; von Glasow and Crutzen, 2004). Measurements at Baring Head $\left(41^{\circ} \mathrm{S}, 179^{\circ} \mathrm{E}\right)$ during February and March 2000 indicate that the $\mathrm{SO}_{2}$ /DMS ratio of clean boundary layer air originating from over the Southern Ocean is approximately 0.060.26 (de Bruyn et al., 2002). Our simulated ratios of surface $\mathrm{SO}_{2} / \mathrm{DMS}$ over the Southern Ocean $\left(40-60^{\circ} \mathrm{S}\right)$ agree with this measured range for the REF, CHEM1, CHEM2 and CHEM3 experiments $(0.19,0.11,0.15$ and 0.13 , respectively).

Examining the global $\mathrm{H}_{2} \mathrm{SO}_{4}$ distribution in the REF simulation reveals that $\mathrm{H}_{2} \mathrm{SO}_{4}$ mixing ratios over the Southern Ocean in DJF are larger than any other region (not shown), consistent with the ECHAM5-HAMMOZ model (Thomas et al., 2010). $\mathrm{H}_{2} \mathrm{SO}_{4}$ concentrations are increased by $\sim 0.015$ to $0.025 \mathrm{ppt}$ relative to REF in the CHEM2 and CHEM3 simulations (Fig. 7c) due to the extra DMS oxidation reactions added.

Figure 8 shows vertical profiles of aerosol mode number concentration and particle dry diameter over the Southern Ocean in the REF and sensitivity simulations. For reference, the mean mass fraction of cloud liquid water in DJF over the Southern Ocean is shown in Fig. 9 to illustrate that the aerosol profiles we examine are situated within the cloud layer. In the SSF simulation, decreasing the dependency of SSA generation on wind speed means that the number concentration of accumulation- and coarse-mode particles decreases by $30 \%-50 \%$ (Fig. $8 \mathrm{~b}$ and c). The particle dry diameters in these modes are largely unchanged (Fig. 8e and f). However, the soluble Aitken mode changes; the number concentration increases by $\sim 40 \%$ in the SSF simulation relative to REF and the average particle dry diameter decreases by $10 \mathrm{~nm}$ (Fig. 8a and d). Initially this was unexpected, as SSA is emitted only into the accumulation and coarse modes in the model, and not the Aitken mode (Mann et al., 2010). The change in the Aitken mode likely comes from smaller non-SSA particles (e.g. sulfate aerosol) being unable to coagulate on larger SSA particles, as these are reduced in number.

In the CHEM simulations, the coarse mode remains largely unchanged regardless of the chemistry scheme used (Fig. 8c, f). In CHEM2 and CHEM3 simulations, there are more smaller particles in the accumulation mode which are smaller on average (Fig. 8b, e), which has implications for cloud microphysics. As discussed earlier, soluble aerosols such as sea salt and sulfate with a diameter $\geq 50 \mathrm{~nm}$ can become activated to $\mathrm{CCN}$, corresponding to a supersaturation of $\sim 0.3 \%$. Simulated $C C N$ and $N_{\mathrm{d}}$ over the Southern Ocean are shown in Fig. 10. In the REF simulation, summertimemean CCN concentrations at $800 \mathrm{~m}$ above the surface average $120 \mathrm{~cm}^{-3}$, which is the same as measurements reported at Cape Grim $\left(41^{\circ} \mathrm{S}, 145^{\circ} \mathrm{E}, 0.23 \%\right.$ supersaturation; Korhonen et al., 2008) and Princess Elisabeth Antarctic Research Station $\left(72^{\circ} \mathrm{S}, 23^{\circ} \mathrm{E}, 0.3 \%\right.$ supersaturation; Herenz et al., 2019). 
(a) DMS
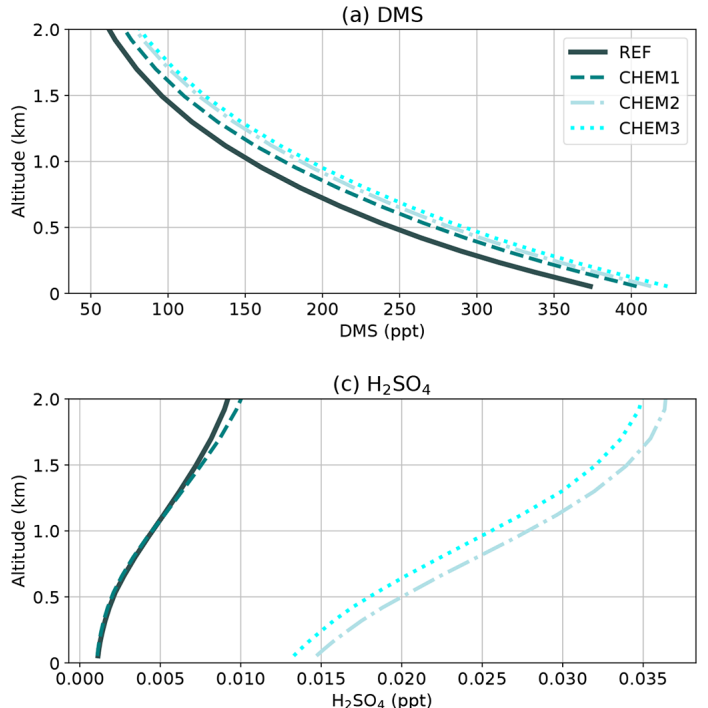

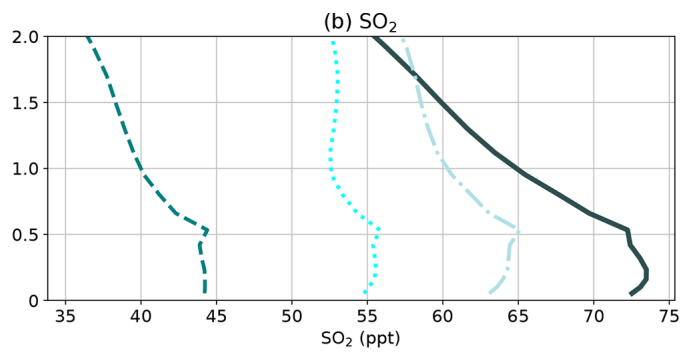

(d) $\mathrm{H}_{2} \mathrm{SO}_{4} / \mathrm{DMS}$

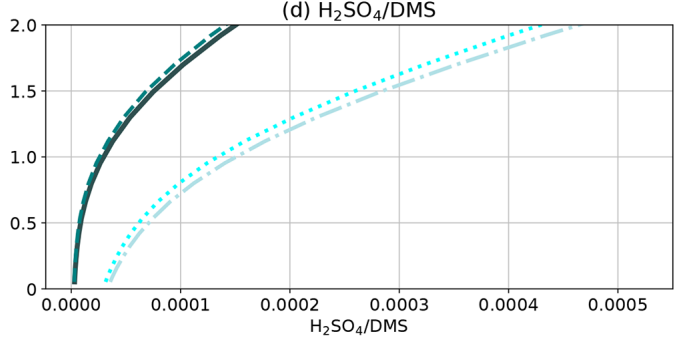

Figure 7. Vertical profiles of trace gas mixing ratios between 40 and $60^{\circ} \mathrm{S}$ in the lowest $2 \mathrm{~km}$ of the atmosphere for the REF and $\mathrm{CHEM}$ simulations. All quantities are climatological means for DJF. (a) DMS; (b) $\mathrm{SO}_{2}$; (c) $\mathrm{H}_{2} \mathrm{SO}_{4}$; (d) the ratio of $\mathrm{H}_{2} \mathrm{SO}_{4} /$ DMS.

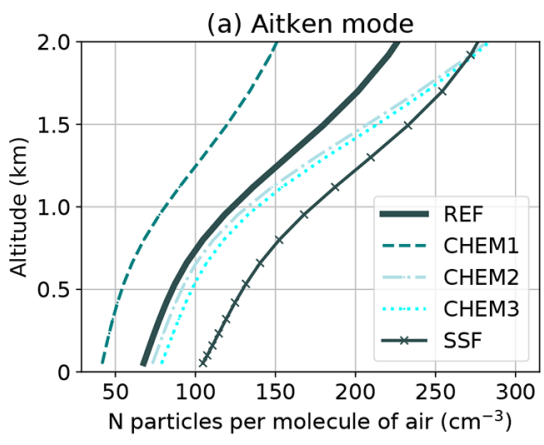

(d) Aitken mode

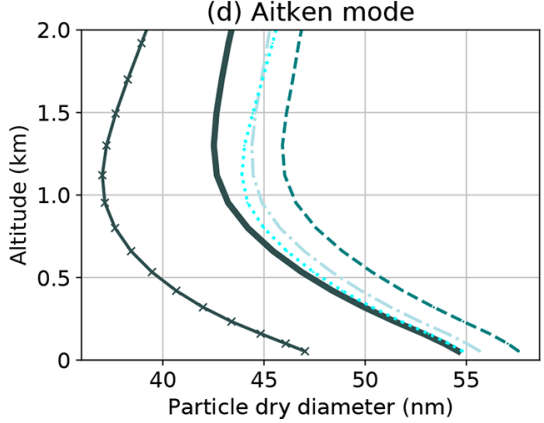

(b) Accumulation mode

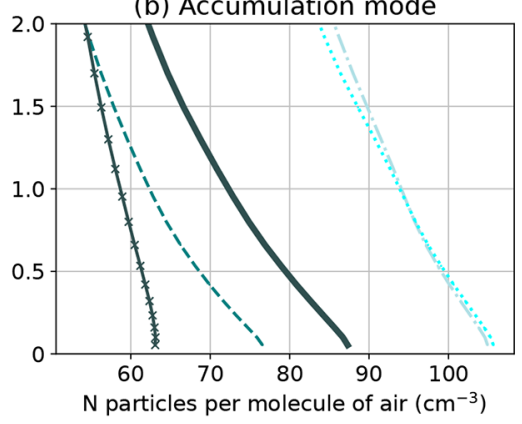

(e) Accumulation mode

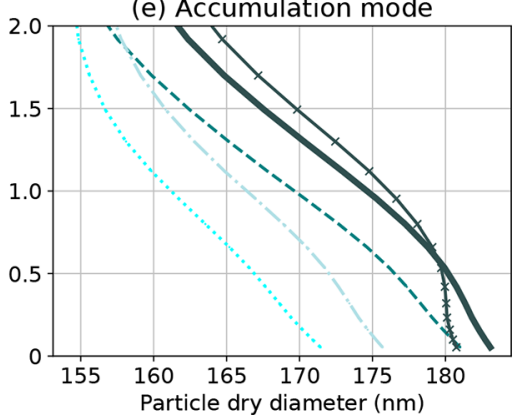

(c) Coarse mode

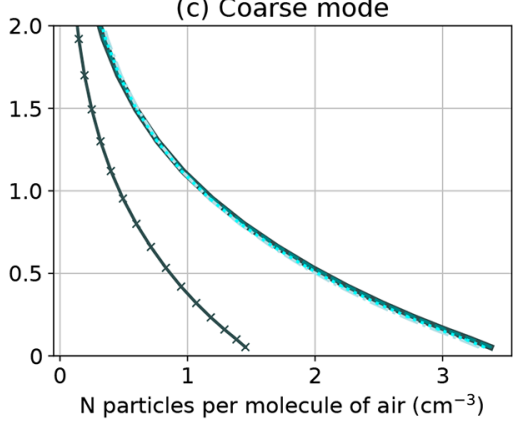

(f) Coarse mode

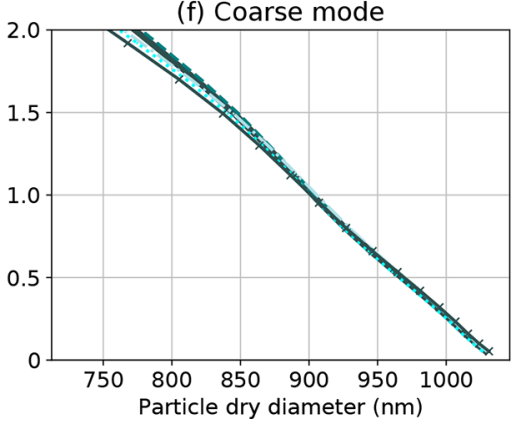

Figure 8. Climatological-mean profiles in DJF between 40 and $60^{\circ} \mathrm{S}$ in the lowest $2 \mathrm{~km}$ of the atmosphere of aerosol mode number concentration $(\mathbf{a}, \mathbf{b}, \mathbf{c})$ and dry diameter $(\mathbf{d}, \mathbf{e}, \mathbf{f})$ for the REF, CHEM and SSF simulations. Panels (a, d) show the soluble Aitken mode; (b, e) the accumulation mode; $(\mathbf{c}, \mathbf{f})$ the coarse mode.

At southern high latitudes, the number fraction of SSA $\mathrm{CCN}$ is larger than any other region on the globe (Quinn et al., 2017). Therefore, due to the reduced aerosol abundance in the SSF simulation, $\mathrm{CCN}$ concentrations also decrease by up to $\sim 13 \%$ relative to REF (Fig. 10a). In the CHEM simulations, $\mathrm{CCN}$ concentrations decrease by $-18 \%$ (CHEM1) to $+25 \%$ (CHEM2 and CHEM3), which is likely linked to the changes in accumulation-mode aerosol shown in Fig. 8. The changes in CCN in the CHEM simulations translate to changes in $N_{\mathrm{d}}$ over the Southern Ocean of $-13 \%$ in CHEM1 to $+20 \%$ in CHEM 2 and CHEM3 (Fig. 10b). Bodas-Salcedo et al. (2019) show that in HadGEM3-GA7.1, the simulated seasonal cycle in $N_{\mathrm{d}}$ over the Southern Ocean is primarily driven by seawater DMS emissions. While the model cap- 


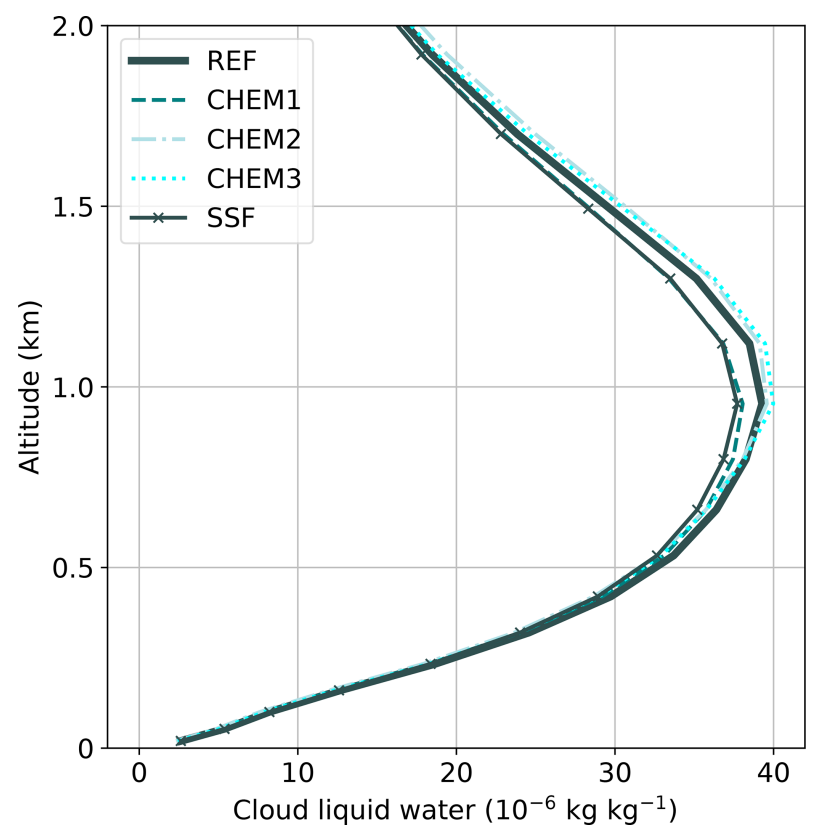

Figure 9. The mass fraction of cloud liquid water in DJF between 40 and $60^{\circ} \mathrm{S}$ in the lowest $2 \mathrm{~km}$ of the atmosphere.

tures the observed seasonality in $N_{\mathrm{d}}$, the magnitude is too low, which was also reported by Mulcahy et al. (2018). However, the CHEM2 and CHEM3 simulations bring the model into better agreement with $N_{\mathrm{d}}$ observations.

Of all the CHEM and CHEM-SSF sensitivity simulations, AOD in the CHEM1 simulation agrees most favourably with MODIS (Fig. 11a), and the root mean square error between 40 and $60^{\circ} \mathrm{S}$ has decreased slightly (from 0.032 to 0.028 ) following the original REF and MODIS comparison (Fig. 1c). However, the seasonal bias remains. The CHEM1-SSF simulation shows good agreement with MODIS AOD during austral winter but underestimates summertime AOD and $N_{\mathrm{d}}$ (Figs. 10b and 11d). CHEM2-SSF and CHEM3-SSF show the reverse; simulated summertime AOD agrees well with MODIS but wintertime AOD is too high, even with the new SSA source function included. In terms of simulating Southern Ocean AOD accurately, we recommend CHEM1 for future studies. However, given the improvements in $N_{\mathrm{d}}$ in the CHEM2, CHEM3, CHEM2-SSF and CHEM3-SSF simulations relative to observations, the CHEM2 and CHEM3 DMS chemistry schemes allow for a more accurate representation of cloud microphysical properties over the Southern Ocean. Furthermore, the CHEM2 and CHEM3 schemes represent a fundamentally improved representation of DMS chemistry over the default scheme and improve process-based understanding of sulfate aerosol formation over the Southern Ocean.

A large source of uncertainty in our investigation into aqueous-phase chemistry lies with the constant cloud water $\mathrm{pH}$ in the model (assumed to be 5 everywhere). Changes in

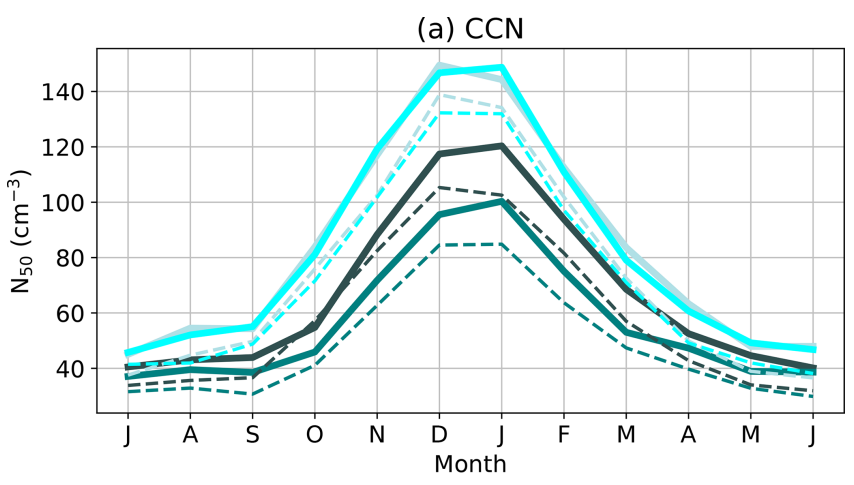

(b) $\mathrm{N}_{d}$

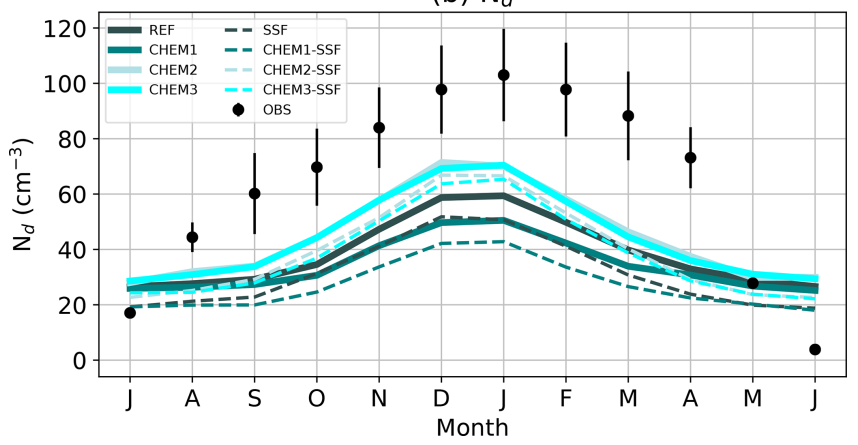

Figure 10. (a) Climatological-mean seasonal cycle in the concentration of cloud condensation nuclei at $800 \mathrm{~m}$ above the surface between 40 and $60^{\circ} \mathrm{S}$. (b) As for panel (a) but showing the cloud droplet number concentration at the cloud top. The $N_{\mathrm{d}}$ observations shown are derived from MODIS data over the period 2003-2015 (Grosvenor et al., 2018). The climatological monthly mean is plotted for all years available of observational data and model data. The error bars on the observations indicate the standard deviation on the climatological monthly mean.

cloud water $\mathrm{pH}$ have substantial impacts on aerosol particle size distributions and $\mathrm{CCN}$ concentrations, particularly in parts of the Northern Hemisphere where reductions in anthropogenic $\mathrm{SO}_{2}$ emissions since the mid-1980s have increased cloud water $\mathrm{pH}$ (Schwab et al., 2016). Turnock et al. (2019) show that the effect of $\mathrm{pH}$ on particles larger than $50 \mathrm{~nm}$ in diameter (which may activate to $\mathrm{CCN}$ ) over the Southern Ocean is not negligible. Aqueous-phase chemistry may also be affected in the model due to the lack of persistent low-lying cloud over the Southern Ocean (Kuma et al., 2019). Aqueous-phase chemistry is more efficient at processing sulfur-containing gases than gas-phase chemistry, but cloud droplets are needed to allow in-cloud droplet chemistry to occur. Future work will focus on these issues and on evaluating changes to clouds and aerosols outside the Southern Ocean region when these changes are implemented. 
(a) CHEM1 minus MODIS [RMSE $=0.028]$

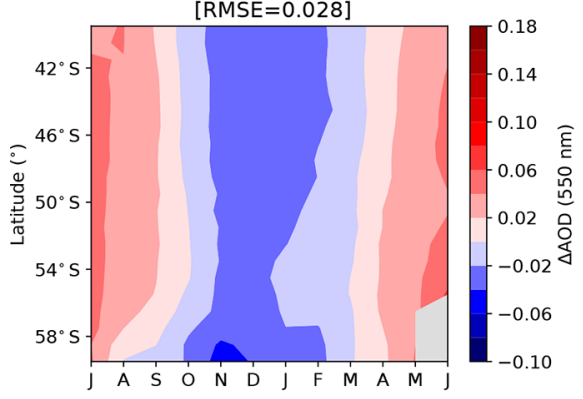

(d) CHEM1-SSF minus MODIS

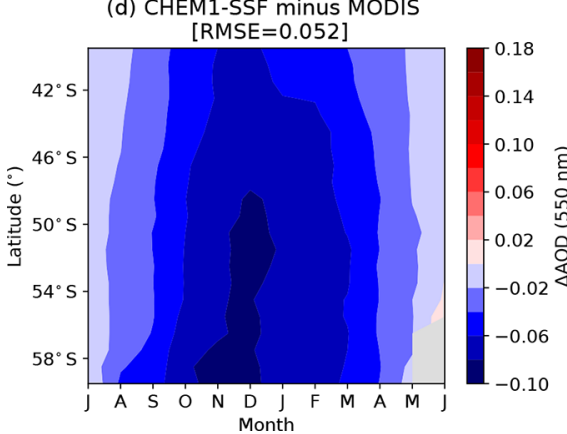

(b) CHEM2 minus MODIS

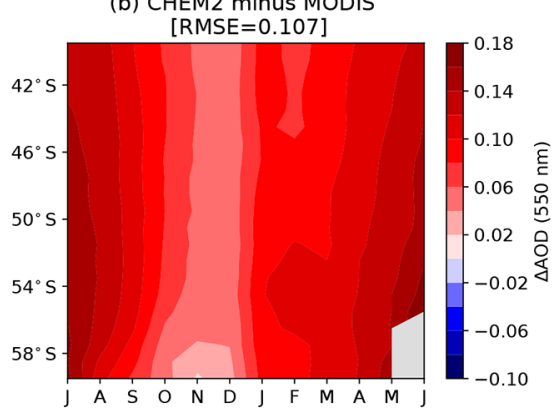

(e) CHEM2-SSF minus MODIS

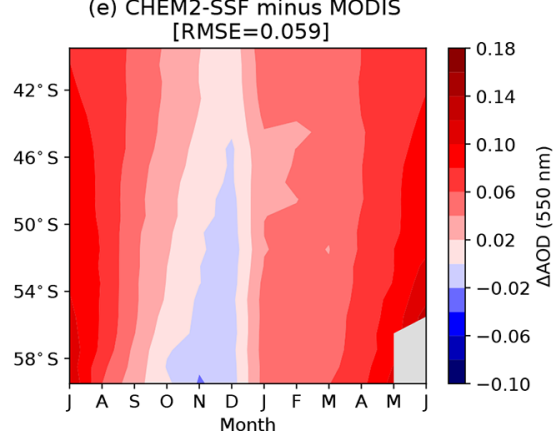

(c) CHEM3 minus MODIS

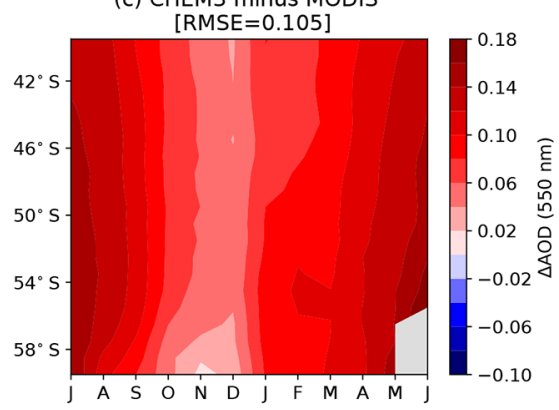

(f) CHEM3-SSF minus MODIS [RMSE $=0.081]$

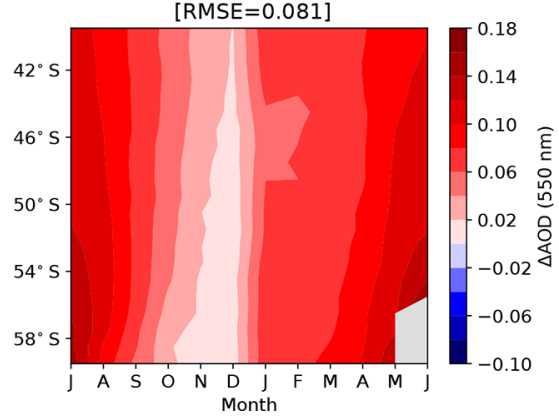

Figure 11. The difference in climatological monthly-mean AOD over the Southern Ocean between MODIS and the HadGEM3-GA7.1 sensitivity simulations: (a) CHEM1; (b) CHEM2; (c) CHEM3; (d) CHEM1-SSF; (e) CHEM2-SSF; (f) CHEM3-SSF. The RMSE is indicated in the title.

\section{Conclusions}

AOD over the Southern Ocean in the HadGEM3-GA7.1-mod chemistry-climate model exhibits seasonal biases compared with MODIS-Aqua collection 6.1 and MISR satellite observations. The model produces too much aerosol in winter (JJA) and too little in summer (DJF). Simulated AOD in winter consists almost entirely of SSA, the production of which depends heavily on the near-surface wind speed. A comparison of MODIS-observed AOD and ERA-Interim wind speeds indicates that the existing SSA source function in the model overestimates the SSA-wind speed dependence. We tested a new SSA source function in which the wind speed dependency is reduced to match SSA measurements made on the 2018 Tangaroa research voyage on the Southern Ocean. Simulated wintertime AOD agrees favourably with observations as a result but points to partially compensating errors in the formulation of sulfate aerosol production, which maximises over the Southern Ocean in summer as a result of marine biogenic activity. We performed simulations to test the sensitivity of Southern Ocean clouds and aerosols to alternative gas-phase and aqueous-phase chemistry schemes associated with sulfate aerosol. The schemes tested here lead to changes in simulated DMS, $\mathrm{SO}_{2}, \mathrm{H}_{2} \mathrm{SO}_{4}$ and aerosol particle sizes and number concentrations. In particular, the CHEM2 and CHEM3 schemes tested lead to increases in CCN and $N_{\mathrm{d}}$ of up to $20 \%$, leading to better agreement between simulated and observed $N_{\mathrm{d}}$. We recommend a combination of the Hartery et al. (2019) SSA source function and either the CHEM2 or CHEM3 DMS chemistry schemes for future studies focused on the Southern Ocean. Our results underscore the importance of atmospheric chemistry for simulating aerosols and cloud microphysics accurately, and imply that future changes in wind speeds or atmospheric composition associated with anthropogenic climate change may impact cloud and aerosol formation over the Southern Ocean, with implications for the radiative balance in this region.

Code and data availability. MODIS and MISR observations were accessed via the Giovanni online data system, developed and maintained by the NASA GES DISC (https:/giovanni.gsfc.nasa.gov/, last access: 17 May 2019). $N_{\mathrm{d}}$ data were obtained from the Centre for Environmental Data Analysis: http://data.ceda.ac.uk/ badc/deposited2018/grosvenor_modis_droplet_conc/ (last access: 17 May 2019). DMS measurements from Amsterdam Island were obtained from the World Data Centre of Greenhouse Gases: https://gaw.kishou.go.jp (last access: 17 May 2019). DMS measurements from the SOAP campaign can be obtained by contacting Mike Harvey: mike.harvey@niwa.co.nz. DMS measurements from the SOIREE campaign are available from Boyd (2009). Cruise data inventory from the R/V Tangaroa 61TG_3052 cruise in the Southern Ocean during 1999 (SOIREE project), Biological and Chemical Oceanography Data Management Office (BCO-DMO), data set version 2009-09-17, are available at http://lod.bco-dmo.org/id/dataset/3212 (last access: 17 May 2019). ERA-Interim data were obtained from the European Centre for 
Medium-Range Weather Forecasts: http://apps.ecmwf.int/datasets/ data/interim-full-moda/levtype $=$ sfc/ (last access: 17 May 2019).

Model simulation data are archived at New Zealand eScience Infrastructure (NeSI) at https://www.nesi.org.nz/ (last access: 4 December 2019) and are available by contacting the corresponding author.

Author contributions. LER implemented model developments, performed model simulations and wrote the manuscript with assistance from all co-authors. SK assisted with experimental design and obtained observational data sets and evaluated the model, together with LER, LB and AS. SH provided the new sea spray aerosol source function tested in the model and performed the binned wind speed-AOD evaluation. MH contributed DMS cruise data and advised on DMS chemistry and aerosols over the Southern Ocean. JPM provided expertise on the representation of aerosols in HadGEM3. JW provided technical expertise in running model simulations. AJM advised on clouds over the Southern Ocean and the use of remote sensing to evaluate the model. OM and VV contributed expertise in running HadGEM3.

Competing interests. The authors declare that they have no conflict of interest.

Acknowledgements. We acknowledge the Deep South National Science Challenge for their support of this research and the UK Met Office for the use of the MetUM. We also wish to acknowledge the contribution of New Zealand eScience Infrastructure (NeSI) high-performance computing facilities to the results of this research. New Zealand's national facilities are provided by NeSI and funded jointly by NeSI's collaborator institutions and through the Ministry of Business, Innovation and Employment's Research Infrastructure programme (https://www.nesi.org.nz/, last access: 4 December 2019). Laura Revell acknowledges China Southern for partial support. Jane Mulcahy was supported by the Met Office Hadley Centre Climate Programme funded by BEIS and Defra (grant no. GA01101). We acknowledge the Cape Grim Science Program for the provision of DMS data from Cape Grim. The Cape Grim Science Program is a collaboration between the Australian Bureau of Meteorology and the CSIRO Australia. We also acknowledge the MISR and MODIS mission scientists and associated NASA personnel for the production of data used in this research effort.

Financial support. This research has been supported by the Deep South National Science Challenge (grant no. C01X1412).

Review statement. This paper was edited by Kostas Tsigaridis and reviewed by two anonymous referees.

\section{References}

Abdul-Razzak, H. and Ghan, S. J.: A parameterization of aerosol activation: 2. Multiple aerosol types, J. Geophys. Res., 105, 68376844, https://doi.org/10.1029/1999jd901161, 2000.

Ayers, G. P. and Gillett, R. W.: DMS and its oxidation products in the remote marine atmosphere: implications for climate and atmospheric chemistry, J. Sea Res., 43, 275-286, https://doi.org/10.1016/S1385-1101(00)00022-8, 2000.

Barnes, I., Hjorth, J., and Mihalopoulos, N.: Dimethyl Sulfide and Dimethyl Sulfoxide and Their Oxidation in the Atmosphere, Chem. Rev., 106, 940-975, https://doi.org/10.1021/cr020529+, 2006.

Bell, T. G., De Bruyn, W., Marandino, C. A., Miller, S. D., Law, C. S., Smith, M. J., and Saltzman, E. S.: Dimethylsulfide gas transfer coefficients from algal blooms in the Southern Ocean, Atmos. Chem. Phys., 15, 1783-1794, https://doi.org/10.5194/acp15-1783-2015, 2015.

Bennartz, R. and Rausch, J.: Global and regional estimates of warm cloud droplet number concentration based on 13 years of AQUA-MODIS observations, Atmos. Chem. Phys., 17, 98159836, https://doi.org/10.5194/acp-17-9815-2017, 2017.

Bodas-Salcedo, A., Mulcahy, J. P., Andrews, T., Williams, K. D., Ringer, M. A., Field, P. R., and Elsaesser, G. S.: Strong dependence of atmospheric feedbacks on mixedphase microphysics and aerosol-cloud interactions in HadGEM3, J. Adv. Model. Earth Sy., 11, 1735-1758, https://doi.org/10.1029/2019ms001688, 2019.

Boucher, O. and Randall, D.: Clouds and Aerosols, in: Climate Change 2013: The Physical Science Basis. Contribution of Working Group I to the Fifth Assessment Report of the Intergovernmental Panel on Climate Change, Cambridge University Press, Cambridge, United Kingdom and New York NY, USA, 2013.

Boucher, O., Moulin, C., Belviso, S., Aumont, O., Bopp, L., Cosme, E., von Kuhlmann, R., Lawrence, M. G., Pham, M., Reddy, M. S., Sciare, J., and Venkataraman, C.: DMS atmospheric concentrations and sulphate aerosol indirect radiative forcing: a sensitivity study to the DMS source representation and oxidation, Atmos. Chem. Phys., 3, 49-65, https://doi.org/10.5194/acp-3-49-2003, 2003.

Boyd, P. W.: Cruise data inventory from the R/V Tangaroa 61TG_3052 cruise in the Southern Ocean during 1999 (SOIREE project), Biological and Chemical Oceanography Data Management Office (BCO-DMO), Dataset version 2009-09-17, available at: http://lod.bco-dmo.org/id/dataset/3212 (last access: 4 December 2019), 2009.

Boyd, P. W. and Law, C. S.: The Southern Ocean Iron RElease Experiment (SOIREE)-introduction and summary, DeepSea Res. Pt. II, 48, 2425-2438, https://doi.org/10.1016/S09670645(01)00002-9, 2001.

Boyd, P. W., Watson, A. J., Law, C. S., Abraham, E. R., Trull, T., Murdoch, R., Bakker, D. C. E., Bowie, A. R., Buesseler, K. O., Chang, H., Charette, M., Croot, P., Downing, K., Frew, R., Gall, M., Hadfield, M., Hall, J., Harvey, M., Jameson, G., LaRoche, J., Liddicoat, M., Ling, R., Maldonado, M. T., McKay, R. M., Nodder, S., Pickmere, S., Pridmore, R., Rintoul, S., Safi, K., Sutton, P., Strzepek, R., Tanneberger, K., Turner, S., Waite, A., and Zeldis, J.: A mesoscale phytoplankton bloom in the polar South- 
ern Ocean stimulated by iron fertilization, Nature, 407, 695-702, https://doi.org/10.1038/35037500, 2000.

Bracegirdle, T. J., Shuckburgh, E., Sallee, J.-B., Wang, Z., Meijers, A. J. S., Bruneau, N., Phillips, T., and Wilcox, L. J.: Assessment of surface winds over the Atlantic, Indian, and Pacific Ocean sectors of the Southern Ocean in CMIP5 models: historical bias, forcing response, and state dependence, J. Geophys. Res.-Atmos., 118, 547-562, https://doi.org/10.1002/jgrd.50153, 2013.

Brooks, S. D. and Thornton, D. C. O.: Marine Aerosols and Clouds, Annu. Rev. Mar. Sci., 10, 289-313, https://doi.org/10.1146/annurev-marine-121916-063148, 2018.

Burkholder, J. B., Sander, S. P., Abbatt, J., Barker, J. R., Huie, R. E., Kolb, C. E., Kurylo, M. J., Orkin, V. L., Wilmouth, D. M., and Wine, P. H.: Chemical Kinetics and Photochemical Data for Use in Atmospheric Studies Evaluation 18. Technical Report, Jet Propulsion Laboratory, California Institute of Technology, Pasadena, USA, 2015.

Ceppi, P., Zelinka, M. D., and Hartmann, D. L.: The response of the Southern Hemispheric eddy-driven jet to future changes in shortwave radiation in CMIP5, Geophys. Res. Lett., 41, 32443250, https://doi.org/10.1002/2014g1060043, 2014.

Chen, Q., Geng, L., Schmidt, J. A., Xie, Z., Kang, H., Dachs, J., Cole-Dai, J., Schauer, A. J., Camp, M. G., and Alexander, B.: Isotopic constraints on the role of hypohalous acids in sulfate aerosol formation in the remote marine boundary layer, Atmos. Chem. Phys., 16, 11433-11450, https://doi.org/10.5194/acp-1611433-2016, 2016

Chen, Q., Schmidt, J. A., Shah, V., Jaeglé, L., Sherwen, T., and Alexander, B.: Sulfate production by reactive bromine: Implications for the global sulfur and reactive bromine budgets, Geophys. Res. Lett., 44, 7069-7078, https://doi.org/10.1002/2017gl073812, 2017

Chen, Q., Sherwen, T., Evans, M., and Alexander, B.: DMS oxidation and sulfur aerosol formation in the marine troposphere: a focus on reactive halogen and multiphase chemistry, Atmos. Chem. Phys., 18, 13617-13637, https://doi.org/10.5194/acp-1813617-2018, 2018.

de Bruyn, W. J., Harvey, M., Cainey, J. M., and Saltzman, E. S.: DMS and $\mathrm{SO}_{2}$ at Baring Head, New Zealand: Implications for the Yield of $\mathrm{SO}_{2}$ from DMS, J. Atmos. Chem., 41, 189-209, https://doi.org/10.1023/a:1014252106572, 2002.

Dee, D. P., Uppala, S. M., Simmons, A. J., Berrisford, P., Poli, P., Kobayashi, S., Andrae, U., Balmaseda, M. A., Balsamo, G., Bauer, P., Bechtold, P., Beljaars, A. C. M., van de Berg, L., Bidlot, J., Bormann, N., Delsol, C., Dragani, R., Fuentes, M., Geer, A. J., Haimberger, L., Healy, S. B., Hersbach, H., Hólm, E. V., Isaksen, L., Kållberg, P., Köhler, M., Matricardi, M., McNally, A. P., Monge-Sanz, B. M., Morcrette, J.-J., Park, B.-K., Peubey, C., de Rosnay, P., Tavolato, C., Thépaut, J.-N., and Vitart, F.: The ERA-Interim reanalysis: configuration and performance of the data assimilation system, Q. J. Roy. Meteorol. Soc., 137, 553597, https://doi.org/10.1002/qj.828, 2011.

Diner, D. J., Beckert, J. C., Reilly, T. H., Bruegge, C. J., Conel, J. E., Kahn, R. A., Martonchik, J. V., Ackerman, T. P., Davies, R., Gerstl, S. A. W., Gordon, H. R., Muller, J., Myneni, R. B., Sellers, P. J., Pinty, B., and Verstraete, M. M.: Multi-angle Imaging SpectroRadiometer (MISR) instrument description and ex- periment overview, IEEE T. Geosci. Remote, 36, 1072-1087, https://doi.org/10.1109/36.700992, 1998.

Du, L., Xu, Y., Ge, M., Jia, L., Yao, L., and Wang, W.: Rate constant of the gas phase reaction of dimethyl sulfide $\left(\mathrm{CH}_{3} \mathrm{SCH}_{3}\right)$ with ozone, Chem. Phys. Lett., 436, 36-40, https://doi.org/10.1016/j.cplett.2007.01.025, 2007.

Fiddes, S. L., Woodhouse, M. T., Nicholls, Z., Lane, T. P., and Schofield, R.: Cloud, precipitation and radiation responses to large perturbations in global dimethyl sulfide, Atmos. Chem. Phys., 18, 10177-10198, https://doi.org/10.5194/acp-18-101772018, 2018.

Flyunt, R., Makogon, O., Schuchmann, M. N., Asmus, K.-D., and von Sonntag, C.: OH-Radical-induced oxidation of methanesulfinic acid. The reactions of the methanesulfonyl radical in the absence and presence of dioxygen, J. Chem. Soc. Perk. T. 2, 5 , 787-792, https://doi.org/10.1039/B009631H, 2001.

Forestieri, S. D., Moore, K. A., Martinez Borrero, R., Wang, A., Stokes, M. D., and Cappa, C. D.: Temperature and Composition Dependence of Sea Spray Aerosol Production, Geophys. Res. Lett., 45, 7218-7225, https://doi.org/10.1029/2018g1078193, 2018.

Fossum, K. N., Ovadnevaite, J., Ceburnis, D., Dall'Osto, M., Marullo, S., Bellacicco, M., Simó, R., Liu, D., Flynn, M., Zuend, A., and O'Dowd, C.: Summertime Primary and Secondary Contributions to Southern Ocean Cloud Condensation Nuclei, Scientific Reports, 8, 13844, https://doi.org/10.1038/s41598-01832047-4, 2018.

Gabric, A., Shephard, J. M., Knight, J. M., Jones, G., and Trevena, A. J.: Correlations between the satellite-derived seasonal cycles of phytoplankton biomass and aerosol optical depth in the Southern Ocean: Evidence for the influence of sea ice, Global Biogeochem. Cy., 19, GB4018, https://doi.org/10.1029/2005GB002546, 2005.

Gabric, A., Matrai, P., Jones, G., and Middleton, J.: The Nexus between Sea Ice and Polar Emissions of Marine Biogenic Aerosols, B. Am. Meteorol. Soc., 99, 61-81, https://doi.org/10.1175/BAMS-D-16-0254.1, 2018.

Garay, M. J., Kalashnikova, O. V., and Bull, M. A.: Development and assessment of a higher-spatial-resolution $(4.4 \mathrm{~km})$ MISR aerosol optical depth product using AERONETDRAGON data, Atmos. Chem. Phys., 17, 5095-5106, https://doi.org/10.5194/acp-17-5095-2017, 2017.

Gershenzon, M., Davidovits, P., Jayne, J. T., Kolb, C. E., and Worsnop, D. R.: Simultaneous Uptake of DMS and Ozone on Water, J. Phys. Chem. A, 105, 7031-7036, https://doi.org/10.1021/jp010696y, 2001.

Glantz, P., Nilsson, E. D., and von Hoyningen-Huene, W.: Estimating a relationship between aerosol optical thickness and surface wind speed over the ocean, Atmos. Res., 92, 58-68, https://doi.org/10.1016/j.atmosres.2008.08.010, 2009.

Gong, S. L.: A parameterization of sea-salt aerosol source function for sub- and super-micron particles, Global Biogeochemical Cycles, 17, 1097, https://doi.org/10.1029/2003GB002079, 2003.

Grosvenor, D. P. and Wood, R.: The effect of solar zenith angle on MODIS cloud optical and microphysical retrievals within marine liquid water clouds, Atmos. Chem. Phys., 14, 7291-7321, https://doi.org/10.5194/acp-14-7291-2014, 2014.

Grosvenor, D. P., Sourdeval, O., Zuidema, P., Ackerman, A., Alexandrov, M. D., Bennartz, R., Boers, R., Cairns, B., Chiu, 
J. C., Christensen, M., Deneke, H., Diamond, M., Feingold, G., Fridlind, A., Hünerbein, A., Knist, C., Kollias, P., Marshak, A., McCoy, D., Merk, D., Painemal, D., Rausch, J., Rosenfeld, D., Russchenberg, H., Seifert, P., Sinclair, K., Stier, P., van Diedenhoven, B., Wendisch, M., Werner, F., Wood, R., Zhang, Z., and Quaas, J.: Remote Sensing of Droplet Number Concentration in Warm Clouds: A Review of the Current State of Knowledge and Perspectives, Rev. Geophys., 56, 409-453, https://doi.org/10.1029/2017RG000593, 2018.

Grythe, H., Ström, J., Krejci, R., Quinn, P., and Stohl, A.: A review of sea-spray aerosol source functions using a large global set of sea salt aerosol concentration measurements, Atmos. Chem. Phys., 14, 1277-1297, https://doi.org/10.5194/acp-141277-2014, 2014.

Hamilton, D. S., Lee, L. A., Pringle, K. J., Reddington, C. L., Spracklen, D. V., and Carslaw, K. S.: Pristine aerosol on a polluted planet, P. Natl. Acad. Sci. USA, 111, 18466-18471, https://doi.org/10.1073/pnas.1415440111, 2014.

Hartery, S., Toohey, D., Revell, L., Sellegri, K., Kuma, P., Harvey, M., and McDonald, A.: Constraining the surface flux of sea spray aerosol from the Southern Ocean, J. Geophys. Res.-Atmos., under review, 2019.

Herenz, P., Wex, H., Mangold, A., Laffineur, Q., Gorodetskaya, I. V., Fleming, Z. L., Panagi, M., and Stratmann, F.: CCN measurements at the Princess Elisabeth Antarctica research station during three austral summers, Atmos. Chem. Phys., 19, 275-294, https://doi.org/10.5194/acp-19-275-2019, 2019.

Hoffmann, E. H., Tilgner, A., Schrödner, R., Bräuer, P., Wolke, R., and Herrmann, H.: An advanced modeling study on the impacts and atmospheric implications of multiphase dimethyl sulfide chemistry, P. Natl. Acad. Sci. USA, 113, 11776-11781, https://doi.org/10.1073/pnas.1606320113, 2016.

Holben, B. N., Eck, T. F., Slutsker, I., Tanré, D., Buis, J. P., Setzer, A., Vermote, E., Reagan, J. A., Kaufman, Y. J., Nakajima, T., Lavenu, F., Jankowiak, I., and Smirnov, A.: AERONET - A Federated Instrument Network and Data Archive for Aerosol Characterization, Remote Sens. Environ., 66, 1-16, https://doi.org/10.1016/S0034-4257(98)00031-5, 1998.

Hyder, P., Edwards, J. M., Allan, R. P., Hewitt, H. T., Bracegirdle, T. J., Gregory, J. M., Wood, R. A., Meijers, A. J. S., Mulcahy, J., Field, P., Furtado, K., Bodas-Salcedo, A., Williams, K. D., Copsey, D., Josey, S. A., Liu, C., Roberts, C. D., Sanchez, C., Ridley, J., Thorpe, L., Hardiman, S. C., Mayer, M., Berry, D. I., and Belcher, S. E.: Critical Southern Ocean climate model biases traced to atmospheric model cloud errors, Nat. Commun., 9, 3625, https://doi.org/10.1038/s41467-018-05634-2, 2018.

Jacob, D. J.: Chemistry of $\mathrm{OH}$ in remote clouds and its role in the production of formic acid and peroxymonosulfate, J. Geophys. Res., 91, 9807-9826, https://doi.org/10.1029/JD091iD09p09807, 1986.

Jaeglé, L., Quinn, P. K., Bates, T. S., Alexander, B., and Lin, J.-T.: Global distribution of sea salt aerosols: new constraints from in situ and remote sensing observations, Atmos. Chem. Phys., 11, 3137-3157, https://doi.org/10.5194/acp-11-3137-2011, 2011.

Kahn, R. A., Gaitley, B. J., Garay, M. J., Diner, D. J., Eck, T. F., Smirnov, A., and Holben, B. N.: Multiangle Imaging SpectroRadiometer global aerosol product assessment by comparison with the Aerosol Robotic Network, J. Geophys. Res., 115, D23209, https://doi.org/10.1029/2010jd014601, 2010.
Kettle, A. J. and Andreae, M. O.: Flux of dimethylsulfide from the oceans: A comparison of updated data sets and flux models, J. Geophys. Res., 105, 26793-26808, https://doi.org/10.1029/2000jd900252, 2000.

Koren, I., Dagan, G., and Altaratz, O.: From aerosol-limited to invigoration of warm convective clouds, Science, 344, 1143-1146, https://doi.org/10.1126/science.1252595, 2014.

Korhonen, H., Carslaw, K. S., Spracklen, D. V., Mann, G. W., and Woodhouse, M. T.: Influence of oceanic dimethyl sulfide emissions on cloud condensation nuclei concentrations and seasonality over the remote Southern Hemisphere oceans: A global model study, J. Geophys. Res., 113, D15204, https://doi.org/10.1029/2007jd009718, 2008.

Kreidenweis, S. M., Walcek, C. J., Feingold, G., Gong, W., Jacobson, M. Z., Kim, C.-H., Liu, X., Penner, J. E., Nenes, A., and Seinfeld, J. H.: Modification of aerosol mass and size distribution due to aqueous-phase $\mathrm{SO}_{2}$ oxidation in clouds: Comparisons of several models, J. Geophys. Res., 108, 4213, https://doi.org/10.1029/2002jd002697, 2003.

Kukui, A., Borissenko, D., Laverdet, G., and Le Bras, G.: Gas-Phase Reactions of $\mathrm{OH}$ Radicals with Dimethyl Sulfoxide and Methane Sulfinic Acid Using Turbulent Flow Reactor and Chemical Ionization Mass Spectrometry, J. Phys. Chem. A, 107, 5732-5742, https://doi.org/10.1021/jp0276911, 2003.

Kuma, P., McDonald, A. J., Morgenstern, O., Alexander, S. P., Cassano, J. J., Garrett, S., Halla, J., Hartery, S., Harvey, M. J., Parsons, S., Plank, G., Varma, V., and Williams, J.: Evaluation of Southern Ocean cloud in the HadGEM3 general circulation model and MERRA-2 reanalysis using ship-based observations, Atmos. Chem. Phys. Discuss., https://doi.org/10.5194/acp-2019201, in review, 2019.

Lamarque, J.-F., Bond, T. C., Eyring, V., Granier, C., Heil, A., Klimont, Z., Lee, D., Liousse, C., Mieville, A., Owen, B., Schultz, M. G., Shindell, D., Smith, S. J., Stehfest, E., Van Aardenne, J., Cooper, O. R., Kainuma, M., Mahowald, N., McConnell, J. R., Naik, V., Riahi, K., and van Vuuren, D. P.: Historical (1850-2000) gridded anthropogenic and biomass burning emissions of reactive gases and aerosols: methodology and application, Atmos. Chem. Phys., 10, 7017-7039, https://doi.org/10.5194/acp-10-7017-2010, 2010.

Lana, A., Bell, T. G., Simó, R., Vallina, S. M., Ballabrera-Poy, J., Kettle, A. J., Dachs, J., Bopp, L., Saltzman, E. S., Stefels, J., Johnson, J. E., and Liss, P. S.: An updated climatology of surface dimethlysulfide concentrations and emission fluxes in the global ocean, Global Biogeochem. Cy., 25, GB1004, https://doi.org/10.1029/2010gb003850, 2011.

Law, C. S., Smith, M. J., Harvey, M. J., Bell, T. G., Cravigan, L. T., Elliott, F. C., Lawson, S. J., Lizotte, M., Marriner, A., McGregor, J., Ristovski, Z., Safi, K. A., Saltzman, E. S., Vaattovaara, P., and Walker, C. F.: Overview and preliminary results of the Surface Ocean Aerosol Production (SOAP) campaign, Atmos. Chem. Phys., 17, 13645-13667, https://doi.org/10.5194/acp-1713645-2017, 2017.

Lee, L. A., Pringle, K. J., Reddington, C. L., Mann, G. W., Stier, P., Spracklen, D. V., Pierce, J. R., and Carslaw, K. S.: The magnitude and causes of uncertainty in global model simulations of cloud condensation nuclei, Atmos. Chem. Phys., 13, 8879-8914, https://doi.org/10.5194/acp-13-8879-2013, 2013. 
Li, J., Michalski, G., Davy, P., Harvey, M., Katzman, T., and Wilkins, B.: Investigating Source Contributions of SizeAggregated Aerosols Collected in Southern Ocean and Baring Head, New Zealand Using Sulfur Isotopes, Geophys. Res. Lett., 45, 3717-3727, https://doi.org/10.1002/2018GL077353, 2018.

Liss, P. S. and Merlivat: Air-sea gas exchange rates: Introduction and synthesis, in: The Role of Air-Sea Exchange in Geochemical Cycling, edited by: Buat-M'enard, P., Springer Netherlands, Norwell, Mass., USA, 1986.

Lucas, D. D. and Prinn, R. G.: Mechanistic studies of dimethylsulfide oxidation products using an observationally constrained model, J. Geophys. Res., 107, ACH 12-1-ACH 12-26, https://doi.org/10.1029/2001jd000843, 2002.

Madry, W. L., Toon, O. B., and O'Dowd, C. D.: Modeled optical thickness of sea-salt aerosol, J. Geophys. Res., 116, D08211, https://doi.org/10.1029/2010jd014691, 2011.

Mahajan, A. S., Fadnavis, S., Thomas, M. A., Pozzoli, L., Gupta, S., Royer, S.-J., Saiz-Lopez, A., and Simó, R.: Quantifying the impacts of an updated global dimethyl sulfide climatology on cloud microphysics and aerosol radiative forcing, J. Geophys. Res.Atmos., 120, 2524-2536, https://doi.org/10.1002/2014jd022687, 2015.

Mann, G. W., Carslaw, K. S., Spracklen, D. V., Ridley, D. A., Manktelow, P. T., Chipperfield, M. P., Pickering, S. J., and Johnson, C. E.: Description and evaluation of GLOMAP-mode: a modal global aerosol microphysics model for the UKCA composition-climate model, Geosci. Model Dev., 3, 519-551, https://doi.org/10.5194/gmd-3-519-2010, 2010.

Martonchik, J. V., Kahn, R. A., and Diner, D. J.: Retrieval of aerosol properties over land using MISR observations, in: Satellite Aerosol Remote Sensing over Land, edited by: Kokhanovsky, A. A. and de Leeuw, G., Springer Praxis Books, Springer, Berlin, Heidelberg, 267-293, https://doi.org/10.1007/978-3-540-693970_9, 2009 .

McCluskey, C. S., DeMott, P. J., Ma, P.-L., and Burrows, S. M.: Numerical Representations of Marine Ice-Nucleating Particles in Remote Marine Environments Evaluated Against Observations, Geophys. Res. Lett., 46, 7838-7847, https://doi.org/10.1029/2018gl081861, 2019.

McCoy, D. T., Burrows, S. M., Wood, R., Grosvenor, D. P., Elliott, S. M., Ma, P.-L., Rasch, P. J., and Hartmann, D. L.: Natural aerosols explain seasonal and spatial patterns of Southern Ocean cloud albedo, Science Advances, 1, e1500157, https://doi.org/10.1126/sciadv.1500157, 2015.

Mehta, M., Singh, R., Singh, A., Singh, N., and Anshumali: Recent global aerosol optical depth variations and trends - A comparative study using MODIS and MISR level 3 datasets, Remote Sens. Environ., 181, 137-150, https://doi.org/10.1016/j.rse.2016.04.004, 2016.

Meskhidze, N. and Nenes, A.: Phytoplankton and Cloudiness in the Southern Ocean, Science, 314, 1419-1423, 2006.

Monahan, E. C., Spiel, D. E., and Davidson, K. L.: A model of marine aerosol generation via whitecaps and wave disruption, in: Oceanic Whitecaps, edited by: Monahan, E. C. and Niocaill, G. M., D. Reidel, Norwell, Mass., 1986.

Morgenstern, O., Braesicke, P., O’Connor, F. M., Bushell, A. C., Johnson, C. E., Osprey, S. M., and Pyle, J. A.: Evaluation of the new UKCA climate-composition model -
Part 1: The stratosphere, Geosci. Model Dev., 2, 43-57, https://doi.org/10.5194/gmd-2-43-2009, 2009.

Mulcahy, J., O'Dowd, C. D., Jennings, S. G., and Ceburnis, D.: Significant enhancement of aerosol optical depth in marine air under high wind conditions, Geophys. Res. Lett., 35, L16810, https://doi.org/10.1029/2008GL034303, 2008.

Mulcahy, J., Jones, C., Sellar, A., Johnson, B., Boutle, I. A., Jones, A., Andrews, T., Rumbold, S. T., Mollard, J., Bellouin, N., Johnson, C. E., Williams, K. D., Grosvenor, D. P., and McCoy, D. T.: Improved Aerosol Processes and Effective Radiative Forcing in HadGEM3 and UKESM1, J. Adv. Model. Earth Sy., 10, 27862805, https://doi.org/10.1029/2018MS001464, 2018.

Murphy, D. M., Anderson, J. R., Quinn, P. K., McInnes, L. M., Brechtel, F. J., Kreidenweis, S. M., Middlebrook, A. M., Pósfai, M., Thomson, D. S., and Buseck, P. R.: Influence of sea-salt on aerosol radiative properties in the Southern Ocean marine boundary layer, Nature, 392, 62-65, https://doi.org/10.1038/32138, 1998.

Myhre, G. and Shindell, D.: Anthropogenic and Natural Radiative Forcing, in: Climate Change 2013: The Physical Science Basis. Contribution of Working Group I to the Fifth Assessment Report of the Intergovernmental Panel on Climate Change, Cambridge University Press, Cambridge, United Kingdom and New York NY, USA, 2013, 2013.

Mårtensson, E. M., Nilsson, E. D., de Leeuw, G., Cohen, L. H., and Hansson, H.-C.: Laboratory simulations and parameterization of the primary marine aerosol production, J. Geophys. Res., 108, 4297, https://doi.org/10.1029/2002jd002263, 2003.

Ocko, I. B. and Ginoux, P. A.: Comparing multiple model-derived aerosol optical properties to spatially collocated ground-based and satellite measurements, Atmos. Chem. Phys., 17, 44514475, https://doi.org/10.5194/acp-17-4451-2017, 2017.

O'Connor, F. M., Johnson, C. E., Morgenstern, O., Abraham, N. L., Braesicke, P., Dalvi, M., Folberth, G. A., Sanderson, M. G., Telford, P. J., Voulgarakis, A., Young, P. J., Zeng, G., Collins, W. J., and Pyle, J. A.: Evaluation of the new UKCA climatecomposition model - Part 2: The Troposphere, Geosci. Model Dev., 7, 41-91, https://doi.org/10.5194/gmd-7-41-2014, 2014.

O’Dowd, C. D., Facchini, M. C., Cavalli, F., Ceburnis, D., Mircea, M., Decesari, S., Fuzzi, S., Yoon, Y. J., and Putaud, J.-P.: Biogenically driven organic contribution to marine aerosol, Nature, 431, 676-680, https://doi.org/10.1038/nature02959, 2004.

Pham, M., Müller, J.-F., Brasseur, G. P., Granier, C., and Mégie, G.: A three-dimensional study of the tropospheric sulfur cycle, J. Geophys. Res., 100, 26061-26092, https://doi.org/10.1029/95jd02095, 1995.

Platnick, S., King, M. D., Ackerman, S. A., Menzel, W. P., Baum, B. A., Riedi, J. C., and Frey, R. A.: The MODIS cloud products: algorithms and examples from Terra, IEEE T. Geosci. Remote, 41, 459-473, https://doi.org/10.1109/TGRS.2002.808301, 2003.

Quinn, P. K., Coffman, D. J., Johnson, J. E., Upchurch, L. M., and Bates, T. S.: Small fraction of marine cloud condensation nuclei made up of sea spray aerosol, Nat. Geosci., 10, 674-679, https://doi.org/10.1038/ngeo3003, 2017.

Remer, L. A., Kleidman, R. G., Levy, R. C., Kaufman, Y. J., Tanré, D., Mattoo, S., Martins, J. V., Ichoku, C., Koren, I., Yu, H., and Holben, B. N.: Global aerosol climatology from the MODIS satellite sensors, J. Geophys. Res., 113, D14S07, https://doi.org/10.1029/2007JD009661, 2008. 
Rosenfeld, D., Andreae, M. O., Asmi, A., Chin, M., de Leeuw, G., Donovan, D. P., Kahn, R., Kinne, S., Kivekäs, N., Kulmala, M., Lau, W., Schmidt, K. S., Suni, T., Wagner, T., Wild, M., and Quaas, J.: Global observations of aerosol-cloudprecipitation-climate interactions, Rev. Geophys., 52, 750-808, https://doi.org/doi:10.1002/2013RG000441, 2014.

Sander, S. P., Friedl, R. R., Golden, D. M., Kurylo, M. J., Moortgat, G. K., Keller-Rudek, H., Wine, P. H., Ravishankara, A. R., Kolb, C. E., Molina, M. J., Finlayson-Pitts, B. J., Huie, R. E., and Orkin, V. L.: Chemical Kinetics and Photochemical Data for Use in Atmospheric Studies Evaluation 15, Technical Report, Jet Propulsion Laboratory, California Institute of Technology, Pasadena, USA, 2006.

Sayer, A. M., Munchak, L. A., Hsu, N. C., Levy, R. C., Bettenhausen, C., and Jeong, M. J.: MODIS Collection 6 aerosol products: Comparison between Aqua's e-Deep Blue, Dark Target, and "merged" data sets, and usage recommendations, J. Geophys. Res.-Atmos., 119, 13965-13989, https://doi.org/10.1002/2014jd022453, 2014

Schuddeboom, A., Varma, V., McDonald, A. J., Morgenstern, O., Harvey, M., Parsons, S., Field, P., and Furtado, K.: Cluster-Based Evaluation of Model Compensating Errors: A Case Study of Cloud Radiative Effect in the Southern Ocean, Geophys. Res. Lett., 46, 3446-3453, https://doi.org/10.1029/2018g1081686, 2019.

Schutgens, N. A. J., Partridge, D. G., and Stier, P.: The importance of temporal collocation for the evaluation of aerosol models with observations, Atmos. Chem. Phys., 16, 1065-1079, https://doi.org/10.5194/acp-16-1065-2016, 2016.

Schwab, J. J., Wolfe, D., Casson, P., Brandt, R., Demerjian, K. L., Husain, L., Dutkiewicz, V. A., Civerolo, K. L., and Rattigan, O. V.: Atmospheric Science Research at Whiteface Mountain, NY: Site Description and History, Aerosol Air Qual. Res., 16, 827-840, https://doi.org/10.4209/aaqr.2015.05.0343, 2016.

Sciare, J., Baboukas, E., and Mihalopoulos, N.: Short-Term Variability of Atmospheric DMS and Its Oxidation Products at Amsterdam Island during Summer Time, J. Atmos. Chem., 39, 281302, https://doi.org/10.1023/a:1010631305307, 2001

Sellegri, K., O’Dowd, C. D., Yoon, Y. J., Jennings, S. G., and de Leeuw, G.: Surfactants and submicron sea spray generation, J. Geophys. Res., 111, D22215, https://doi.org/10.1029/2005jd006658, 2006

Shindell, D. T., Lamarque, J.-F., Schulz, M., Flanner, M., Jiao, C., Chin, M., Young, P. J., Lee, Y. H., Rotstayn, L., Mahowald, N., Milly, G., Faluvegi, G., Balkanski, Y., Collins, W. J., Conley, A. J., Dalsoren, S., Easter, R., Ghan, S., Horowitz, L., Liu, X., Myhre, G., Nagashima, T., Naik, V., Rumbold, S. T., Skeie, R., Sudo, K., Szopa, S., Takemura, T., Voulgarakis, A., Yoon, J.-H., and Lo, F.: Radiative forcing in the ACCMIP historical and future climate simulations, Atmos. Chem. Phys., 13, 2939-2974, https://doi.org/10.5194/acp-13-2939-2013, 2013.

Smirnov, A., Holben, B. N., Eck, T. F., Dubovik, O., and Slutsker, I.: Effect of wind speed on columnar aerosol optical properties at Midway Island, J. Geophys. Res., 108, 4802, https://doi.org/doi:10.1029/2003JD003879, 2003.

Smith, M. J., Walker, C. F., Bell, T. G., Harvey, M. J., Saltzman, E. S., and Law, C. S.: Gradient flux measurements of seaair DMS transfer during the Surface Ocean Aerosol Produc- tion (SOAP) experiment, Atmos. Chem. Phys., 18, 5861-5877, https://doi.org/10.5194/acp-18-5861-2018, 2018.

Sofiev, M., Soares, J., Prank, M., de Leeuw, G., and Kukkonen, J.: A regional-to-global model of emission and transport of sea salt particles in the atmosphere, J. Geophys. Res., 116, D21302, https://doi.org/10.1029/2010jd014713, 2011.

Spada, M., Jorba, O., Pérez García-Pando, C., Janjic, Z., and Baldasano, J. M.: On the evaluation of global sea-salt aerosol models at coastal/orographic sites, Atmos. Environ., 101, 41-48, https://doi.org/10.1016/j.atmosenv.2014.11.019, 2015.

Thomas, M. A., Suntharalingam, P., Pozzoli, L., Rast, S., Devasthale, A., Kloster, S., Feichter, J., and Lenton, T. M.: Quantification of DMS aerosol-cloud-climate interactions using the ECHAM5-HAMMOZ model in a current climate scenario, Atmos. Chem. Phys., 10, 7425-7438, https://doi.org/10.5194/acp10-7425-2010, 2010.

Thomason, L. W., Ernest, N., Millán, L., Rieger, L., Bourassa, A., Vernier, J.-P., Manney, G., Luo, B., Arfeuille, F., and Peter, T.: A global space-based stratospheric aerosol climatology: 1979-2016, Earth Syst. Sci. Data, 10, 469-492, https://doi.org/10.5194/essd-10-469-2018, 2018.

Toth, T. D., Zhang, J., Campbell, J. R., Reid, J. S., Shi, Y., Johnson, R. S., Smirnov, A., Vaughan, M. A., and Winker, D. M.: Investigating enhanced Aqua MODIS aerosol optical depth retrievals over the mid-to-high latitude Southern Oceans through intercomparison with co-located CALIOP, MAN, and AERONET data sets, J. Geophys. Res.-Atmos., 118, 4700-4714, https://doi.org/10.1002/jgrd.50311, 2013.

Trenberth, K. E. and Fasullo, J. T.: Simulation of Present-Day and Twenty-First-Century Energy Budgets of the Southern Oceans, J. Climate, 23, 440-454, https://doi.org/10.1175/2009jcli3152.1, 2010 .

Trevena, A. J. and Jones, G. B.: Dimethylsulphide and dimethylsulphoniopropionate in Antarctic sea ice and their release during sea ice melting, Mar. Chem., 98, 210-222, https://doi.org/10.1016/j.marchem.2005.09.005, 2006.

Troy, R. C. and Margerum, D. W.: Non-metal redox kinetics: hypobromite and hypobromous acid reactions with iodide and with sulfite and the hydrolysis of bromosulfate, Inorg. Chem., 30, 3538-3543, https://doi.org/10.1021/ic00018a028, 1991.

Turner, S. M., Harvey, M. J., Law, C. S., Nightingale, P. D., and Liss, P. S.: Iron-induced changes in oceanic sulfur biogeochemistry, Geophys. Res. Lett., 31, L14307, https://doi.org/10.1029/2004GL020296, 2004.

Turnock, S. T., Mann, G. W., Woodhouse, M. T., Dalvi, M., O'Connor, F. M., Carslaw, K. S., and Spracklen, D. V.: The Impact of Changes in Cloud Water $\mathrm{pH}$ on Aerosol Radiative Forcing, Geophys. Res. Lett., 46, 4039-4048, https://doi.org/10.1029/2019gl082067, 2019.

Twomey, S.: The Influence of Pollution on the Shortwave Albedo of Clouds, J. Atmos. Sci., 34, 1149-1152, https://doi.org/10.1175/1520 0469(1977)034<1149:TIOPOT>2.0.CO;2, 1977.

Vallina, S. M., Simó, R., Gassó, S., de Boyer-Montégut, C., del Río, E., Jurado, E., and Dachs, J.: Analysis of a potential "solar radiation dose-dimethylsulfide-cloud condensation nuclei" link from globally mapped seasonal correlations, Global Biogeochem. Cy., 21, GB2004, https://doi.org/10.1029/2006gb002787, 2007. 
von Glasow, R. and Crutzen, P. J.: Model study of multiphase DMS oxidation with a focus on halogens, Atmos. Chem. Phys., 4, 589608, https://doi.org/10.5194/acp-4-589-2004, 2004.

Walker, C. F., Harvey, M. J., Smith, M. J., Bell, T. G., Saltzman, E. S., Marriner, A. S., McGregor, J. A., and Law, C. S.: Assessing the potential for dimethylsulfide enrichment at the sea surface and its influence on air-sea flux, Ocean Sci., 12, 1033-1048, https://doi.org/10.5194/os-12-1033-2016, 2016.

Walters, D., Baran, A. J., Boutle, I., Brooks, M., Earnshaw, P., Edwards, J., Furtado, K., Hill, P., Lock, A., Manners, J., Morcrette, C., Mulcahy, J., Sanchez, C., Smith, C., Stratton, R., Tennant, W., Tomassini, L., Van Weverberg, K., Vosper, S., Willett, M., Browse, J., Bushell, A., Carslaw, K., Dalvi, M., Essery, R., Gedney, N., Hardiman, S., Johnson, B., Johnson, C., Jones, A., Jones, C., Mann, G., Milton, S., Rumbold, H., Sellar, A., Ujiie, M., Whitall, M., Williams, K., and Zerroukat, M.: The Met Office Unified Model Global Atmosphere 7.0/7.1 and JULES Global Land 7.0 configurations, Geosci. Model Dev., 12, 1909-1963, https://doi.org/10.5194/gmd-12-1909-2019, 2019.

Warneck, P.: Chemistry of the Natural Atmosphere, Academic Press, San Diego, 2000.

Weisenstein, D. K., Yue, G. K., Ko, M. K. W., Sze, N.-D., Rodriguez, J. M., and Scott, C. J.: A two-dimensional model of sulfur species and aerosols, J. Geophys. Res., 102, 13019-13035, https://doi.org/10.1029/97jd00901, 1997.
West, R. E. L., Stier, P., Jones, A., Johnson, C. E., Mann, G. W., Bellouin, N., Partridge, D. G., and Kipling, Z.: The importance of vertical velocity variability for estimates of the indirect aerosol effects, Atmos. Chem. Phys., 14, 6369-6393, https://doi.org/10.5194/acp-14-6369-2014, 2014.

Woodhouse, M. T., Carslaw, K. S., Mann, G. W., Vallina, S. M., Vogt, M., Halloran, P. R., and Boucher, O.: Low sensitivity of cloud condensation nuclei to changes in the sea-air flux of dimethyl-sulphide, Atmos. Chem. Phys., 10, 7545-7559, https://doi.org/10.5194/acp-10-7545-2010, 2010.

Woodward, S.: Modeling the atmospheric life cycle and radiative impact of mineral dust in the Hadley Centre climate model, J. Geophys. Res., 106, 18155-18166, https://doi.org/10.1029/2000jd900795, 2001.

Zhu, L., Nenes, A., Wine, P. H., and Nicovich, J. M.: Effects of aqueous organosulfur chemistry on particulate methanesulfonate to non-sea salt sulfate ratios in the marine atmosphere, J. Geophys. Res., 111, D05316, https://doi.org/10.1029/2005jd006326, 2006. 